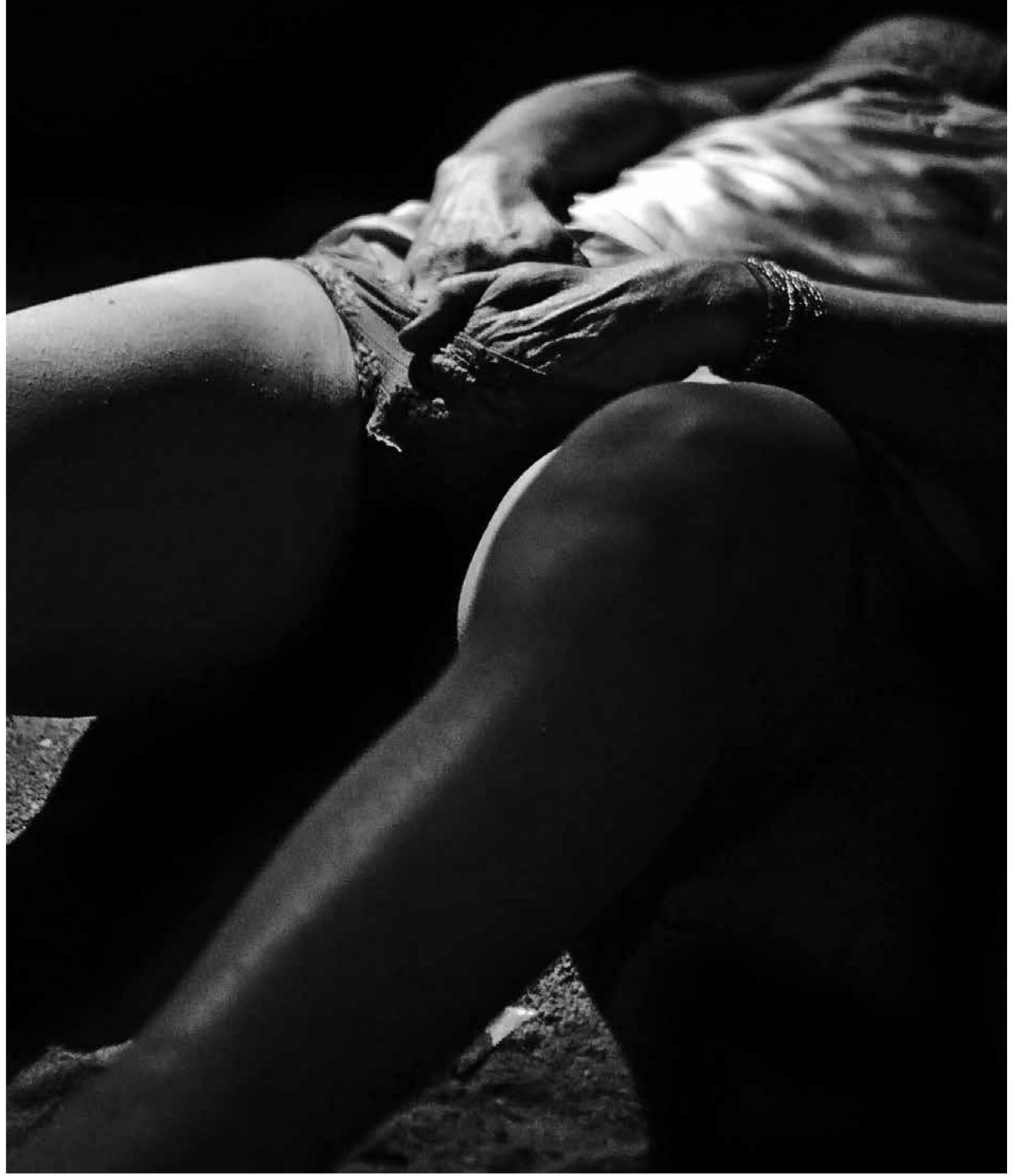




\section{Mónica Calle: Acreditar e existir nas palavras}

MARIA JOÃO BRILHANTE, EUNICE TUDELA DE AZEVEDO E GUSTAVO VICENTE

Nasceu em Madrid. Cedo veio para Portugal, onde, no fim da década de 1980, fez o Curso de Formação de Actores da Escola Superior de Teatro e Cinema e se tornou actriz, encenadora e uma das mais fortes figuras femininas do teatro português contemporâneo. Mónica Calle iniciou a sua actividade profissional no Teatro da Cornucópia, mas rapidamente começou a trilhar o seu próprio caminho. Em 1992, num rés-do-chão da rua dos Remolares, cedido pelo Sindicato dos Estivadores do Porto de Lisboa, Calle deu início à grande aventura que é a Casa Conveniente. O projecto nasceu e cresceu no Cais do Sodré, numa altura em que o bairro ainda não havia sofrido as transformações que lhe retiraram o seu carácter marginal. A Casa Conveniente manteve-se no Cais - ocupando, a partir de 2004, o espaço do antigo bar Lusitano, na rua Nova do Carvalho -, vivendo essas transformações, durante duas décadas. A viagem da Casa Conveniente até à «Zona Não Vigiada», a Zona J, em Chelas, iniciada em 2012, marca um novo e importante ciclo para a companhia. Calle falou-nos do seu percurso, dos seus encontros e do itinerário traçado numa certa marginalidade, mas também do seu entusiasmo com o tempo presente da criação de «algo maior» e impensável, sempre a partir do lugar vital da palavra escrita no seu trabalho artístico.

Podíamos começar por uma das questões que queríamos perceber, que é justamente este teu atlas, este périplo que fazes por diversos sítios da cidade: antes Cais do Sodré, agora a passagem para aqui, mas também podemos situar a experiência com Vale de Judeus no início, não é?

Sim.

E como é na verdade tomar o pulso, conhecer os sítios para onde se vai sem ser com aquela atitude de chegar, faço as minhas coisas e se quiserem vir cá ver venham ver. Como é apalpar o terreno e ver um bocadinho quem são as pessoas? Gente de cá que se aproxima e pode fazer a passagem para outras pessoas...

É isso que tem estado a acontecer, ou seja... a vinda para cá [Zona J] não foi uma decisão propriamente conceptual. Ou seja, não pensei assim: «Ai, agora vou trabalhar para a Zona J.» É a Zona J por uma razão muito concreta: tem que ver com Vale de Judeus. Algumas 
das pessoas do grupo de teatro [de Vale de Judeus] foram acabando as penas e continuaram a trabalhar connosco cá fora. Portanto, foi uma inevitabilidade.

\section{Estás a falar do René...}

O René, o Boss, o Luís Afonso... Curiosamente, todos eles eram da Zona J. Na realidade, a minha vinda cá começou por ser vir jantar e almoçar em casa deles. Quando eles acabaram as penas, começaram a trabalhar comigo. O primeiro a sair foi o Boss, e uma das coisas que ele sempre nos disse foi que havia imensas pessoas no bairro dele com muito talento e uma série de capacidades e começou a levá-las para o Cais do Sodré. Com o Bruno Candé, por exemplo, foi assim. Com o Fábio, que está a dançar agora connosco, e uma série de bailarinos, também. Portanto, começaram por ir ver os espectáculos e eu comecei a encontrar soluções nas minhas encenações para os poder integrar. Do ponto de vista criativo, o meu trabalho foi-se transformando e confrontei-me com a questão da dança, sobre a qual nunca tinha pensado de uma forma propriamente concreta e que de repente comecei a pôr nos espectáculos. Simultaneamente, o que estava a acontecer? Eu sabia que o Cais do Sodré rapidamente iria deixar de fazer sentido e foi isso que aconteceu. O Cais do Sodré foi-se transformando ao longo do tempo. Por outro lado, também, o meu trabalho dava para incluir outras gerações. Começou a fazer sentido vir para aqui desenvolver o meu trabalho. Porque, de repente, via aqui em potência uma série de pessoas que queriam e precisavam. Percebi que de alguma forma fazia sentido vir para aqui, também, em relação ao meu trabalho, porque eu de facto estava a começar a evoluir para outro sítio e este era o contexto em que as coisas se ajustavam. Eu pensei que a progressão seria mais lenta, ou seja, que de alguma forma iria precisar de alguns anos para fazer essa transição. De alguma maneira, aquilo que também me interessa não é só vir para aqui trabalhar, também tem que ver com essa dificuldade em fazer que as pessoas daqui saiam daqui. É criar, de facto, uma ideia de fluxo e de fazer que as pessoas daqui saiam daqui e que as pessoas de fora venham para cá. Só assim é que faz sentido. Isso também foi acontecendo a partir do momento em que comecei a trabalhar com eles, porque nos últimos dois anos 
só fiz espectáculos em salas convencionais: no Maria Matos, na Culturgest, em Torres Novas. Estive sempre em palcos grandes e algumas destas pessoas começaram também a ir ver espectáculos ao Maria Matos, à Culturgest, a salas onde nunca tinham ido. É um trabalho no tempo; é lento, é progressivo. A verdade é que depois isto tudo se acelerou e, portanto, de repente... Pedi este espaço à câmara e comecei a pensar nisto no final de 2011. Demorou muito tempo. Nós só tivemos o espaço... vai fazer sexta-feira [31 de Julho] um ano que nos entregaram a chave. A «chave». A chave de uma porta que não existia. Houve assim uma cerimónia protocolar de entrega de uma chave de uma porta que não havia. Passou um ano e ainda não começámos as obras. Em 2012 não entreguei a candidatura [à Direcção-Geral das Artes], portanto, foram dois anos em que houve um corte muito mais violento do que eu tinha previsto.

Era uma questão também que queríamos pôr: a relação com o contexto institucional.

Foi violentíssimo, tudo foi violentíssimo. Fechei a Casa Conveniente. Deixei de ter sítio. Estava à espera de ter, mas ainda não existia. Aliás, este espectáculo da Mónica [Garnel], o Drive-in, foi pensado exactamente nesse momento em que não tínhamos um sítio. Tal como toda a ideia de um caminho, da cartografia dos sete pecados. Nós não tínhamos ainda um espaço. Sabíamos que íamos ter, mas ele ainda não existia. Foi um caminho, de facto, muito violento, um corte abrupto. Ou seja, deixámos de ter financiamento, deixámos de ter sítio. Houve um ano de co-produções, em que andámos a fazer espectáculos nos teatros. Ou seja, de facto procurou-se condições para trabalhar. Nunca tivemos muito dinheiro, mas de alguma forma tivemos sempre um espaço. Quando comecei no Cais do Sodré, na altura, depois de acabar a escola, não havia financiamentos sequer. Portanto, as circunstâncias eram completamente diferentes. Havia muito poucas estruturas. Ou seja, a única possibilidade que qualquer um de nós tinha para começar a trabalhar era encontrar um espaço, porque isso garante uma liberdade, mesmo sem dinheiro. Foi assim que eu, a Lúcia [Sigalho], o João Garcia Miguel, o Útero, a Garagem começámos. Fomos à procura de um espaço para podermos começar a trabalhar e durante cinco anos foi assim que trabalhei. Só passei a ter financiamentos cinco anos depois 


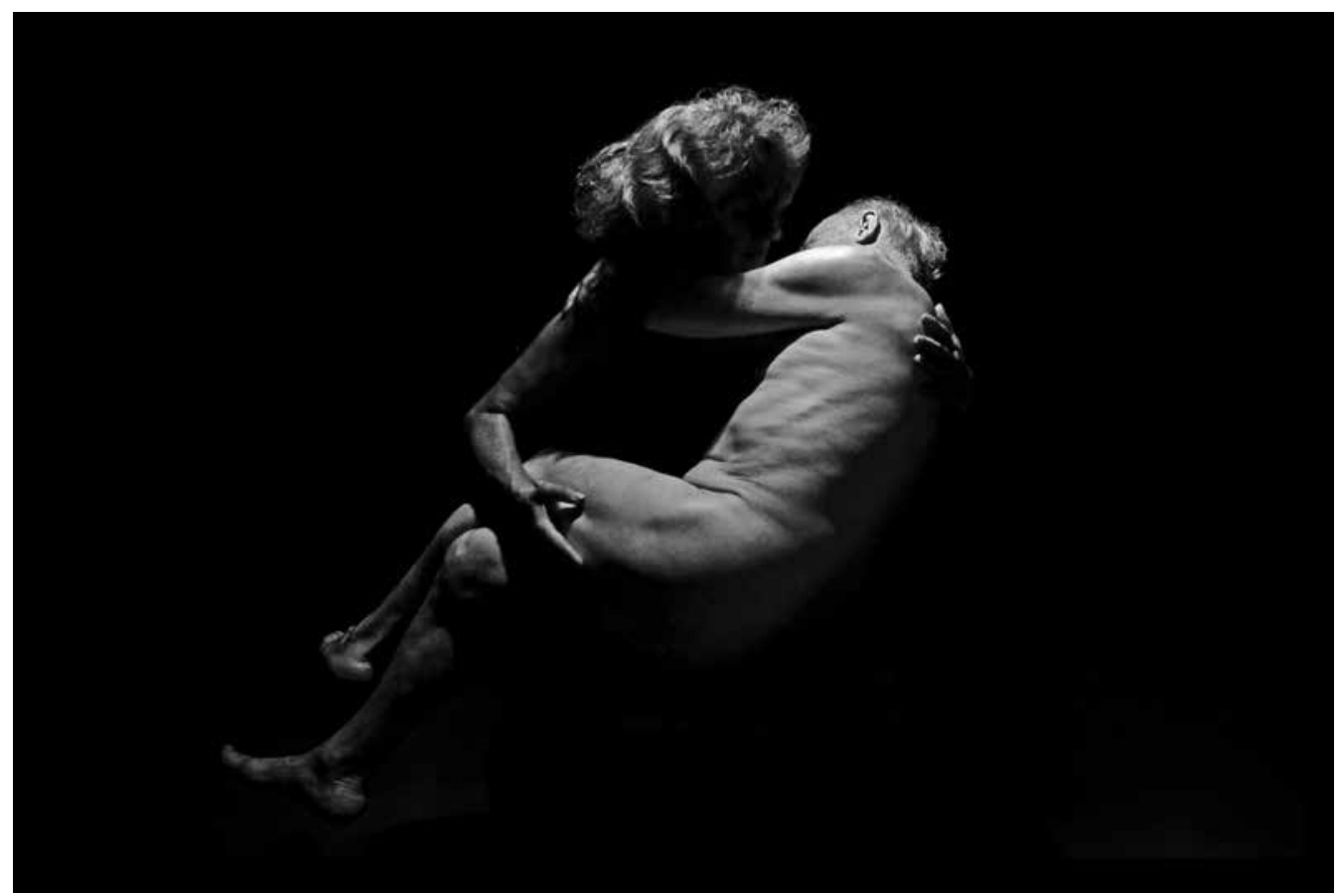

ILUMINAÇÕES, A PARTIR DE RIMBAUD, COMPANHIA MAIOR/CENTRO CULTURAL DE BELÉM, 2012 (KIMBERLEY RIBEIRO, VÍTOR LOPES), [F] BRUNO SIMÃO

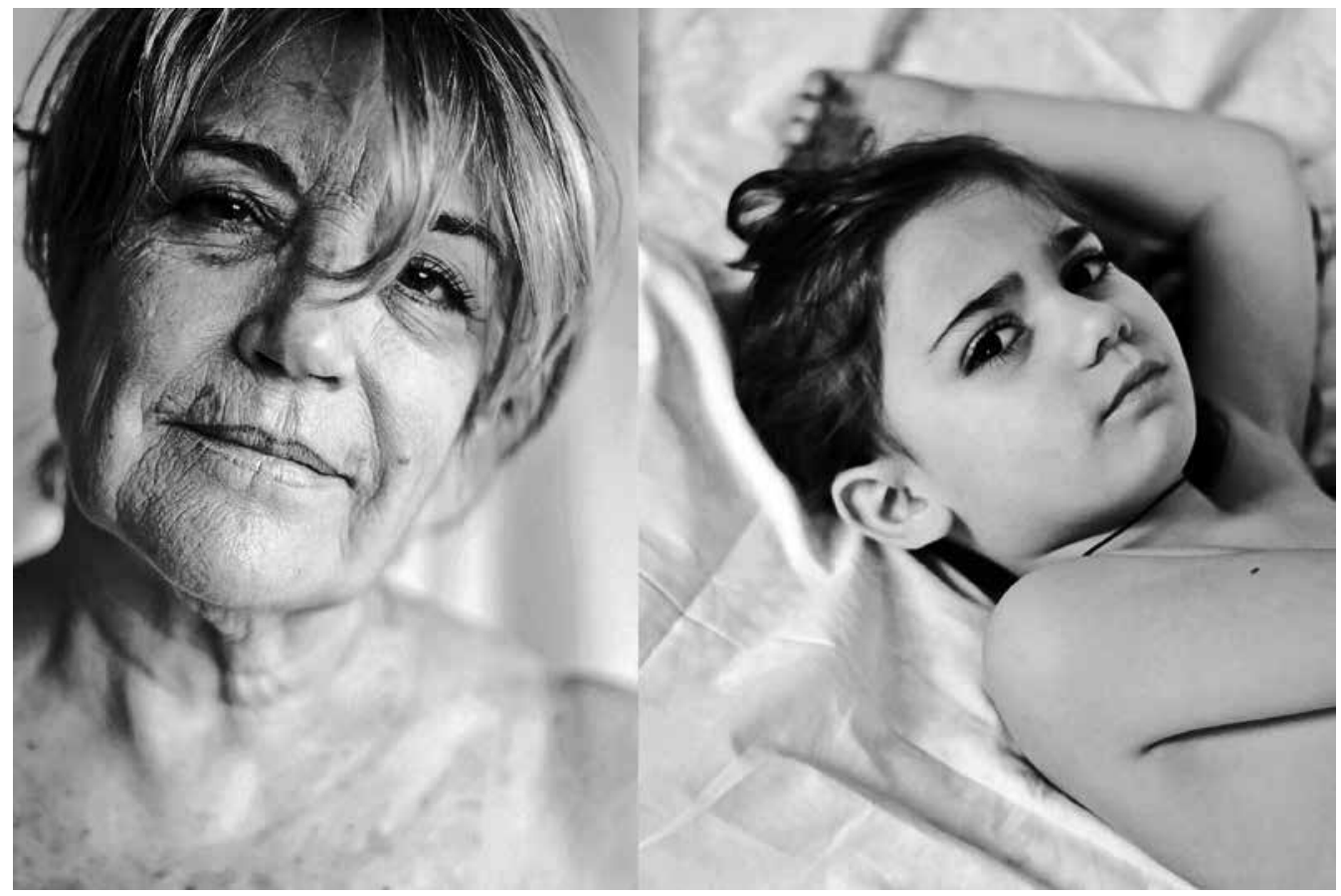

OS MEUS SENTIMENTOS, DE DULCE MARIA CARDOSO, CASA CONVENIENTE/CULTURGEST, 2013 (MÃE DE MÓNICA CALLE, ANA), [F] BRUNO SIMÃO 


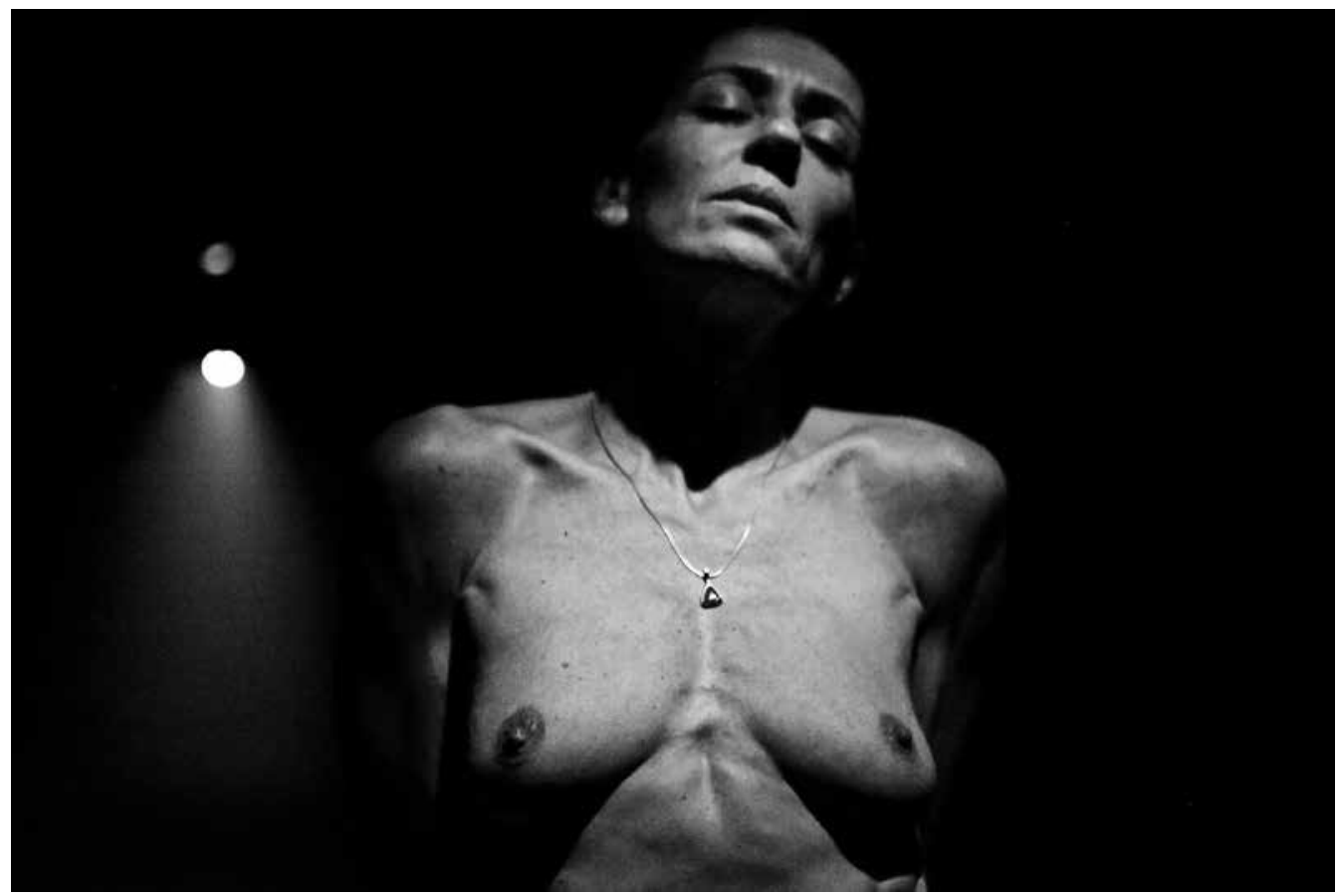

A VIRGEM DOIDA, A PARTIR DE RIMBAUD, CASA CONVENIENTE, 2012 (MÓNICA CALLE), [F] DE ENSAIO BRUNO SIMÃO

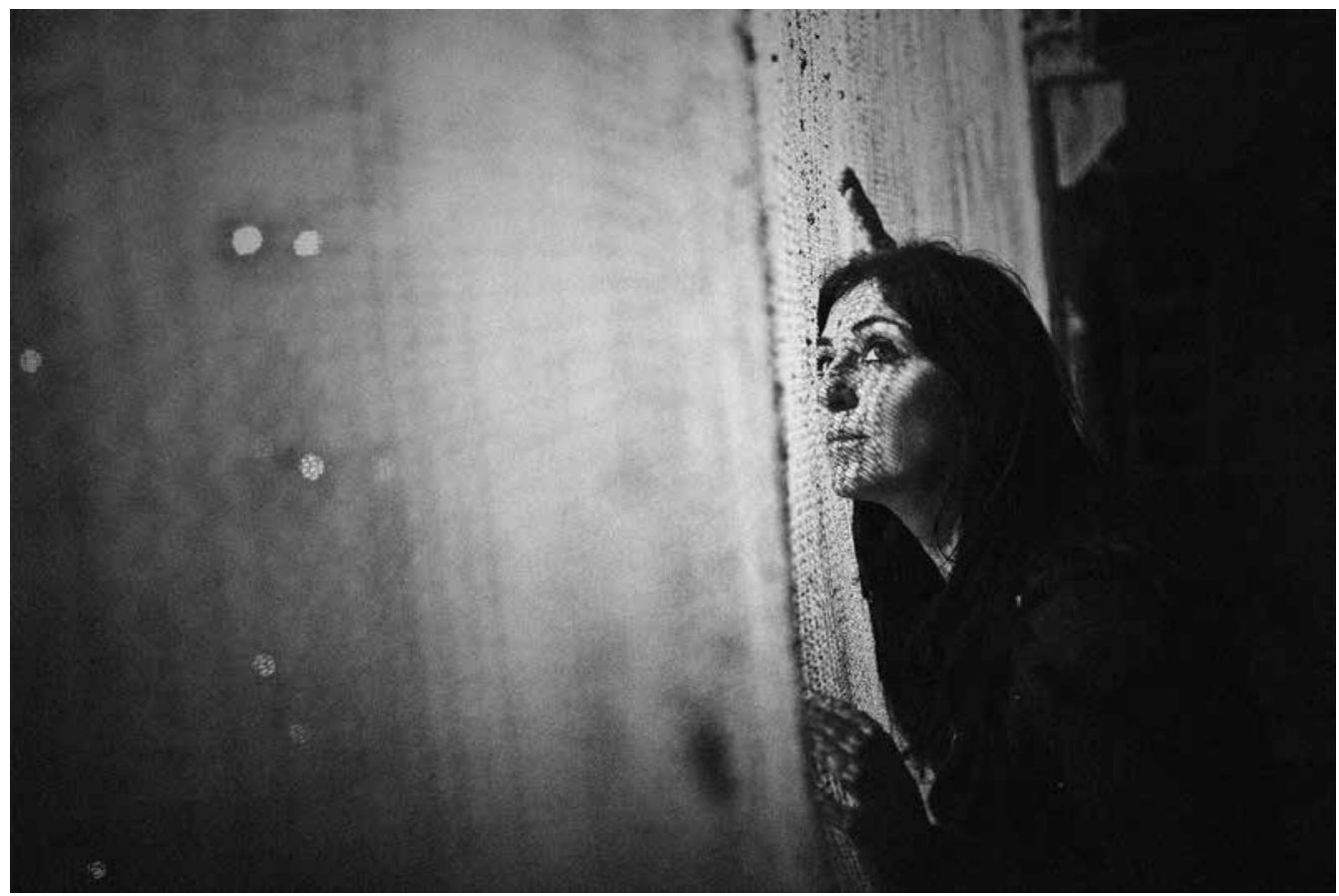

A BOA ALMA..., A PARTIR DE BERTOLT BRECHT, CASA CONVENIENTE, 2015 (MÓNICA CALLE), [F] BRUNO SIMÃO 
de ter começado a trabalhar. Desde $A$ Virgem Doida até ter pela primeira vez um subsídio, passaram cinco anos. Mas havia o espaço. Passaram quase vinte e cinco anos e de facto foi mesmo um recomeço total. Um trabalho vil, muito mais violento, porque eu tenho quase cinquenta anos. Passaram muitos anos, o sítio já não é o mesmo. Há uma equipa grande e que foi... Mas ao mesmo tempo tudo isto faz sentido. Porque é um fecho de um ciclo e há mesmo a necessidade de recomeço real, em todos os sentidos. É mesmo recomeçar de verdade. Outra vez. E, também, como não há nada, essa procura, neste contexto vai tentando ser feita lentamente. Sem pressa. E isso também foi uma coisa a que nos obrigámos. Há uma urgência, não é? Porque é desesperante. Por um lado, porque tem que ver com a vida. A única coisa que fizemos - e que foi muito - foi reconstruir pouco a pouco. $\mathrm{O}$ que andámos a fazer foi construir candidaturas, para tentarmos ir montando, pouco a pouco, lentamente. Começámos com o apoio da Gulbenkian. Depois foi o pontual, o Bip-Zip, o anual. Só concorremos a um ano da Direcção-Geral das Artes. Achámos que era honesto, porque temos de avaliar o que vai acontecer aqui para percebermos onde vamos a seguir. Tudo isto nos está a transformar e sabemos que é preciso estarmos aqui e começarmos a trabalhar, para percebermos para onde vamos. E ainda estamos a percorrer essas etapas. Primeiro, para tentar ganhar uma serenidade que tem que ver com o tempo, com o tempo que é necessário. Com calma. Perceber... Já que estamos mesmo a começar, que esse começo seja com toda a seriedade e com toda a honestidade, sem ceder a medos. Porque o medo existe.

\section{Essa urgência em recomeçar, associas só ao facto de se terem} mudado para um espaço novo ou há outras razões?

É tudo, tudo, tudo. É o trabalho... com o texto. Depois no meio disto tudo há sempre dúvidas, não é? Por isso é tão difícil. A Boa Alma foi o trabalho mais difícil da minha vida, por todas as razões. Mesmo o espectáculo mais difícil que já fiz; o processo mais difícil que já fiz. Tem que ver com isso, tem que ver com o sítio e com o que eu queria dizer. Isto aconteceu-me quando fiz A Virgem Doida. Tinha acabado a escola e tinha a intuição do que andava à procura. Mas era uma intuição; não sabia; era preciso experimentar. Aconteceu - às vezes acontecem estes encontros felizes e, de facto, mesmo sem nós sabermos estamos à frente ou em sintonia - e o que aconteceu foi que, intuitivamente, 
toda a proposta - o estar no Cais do Sodré, a proposta do espectáculo - encontrou um contexto social e histórico que estava certo, ou seja, o meu trabalho encontrou-se numa coisa muito maior que tem que ver com um contexto que me ultrapassa, e só te apercebes depois. Agora voltei a sentir isso. Estou a sentir - estou a perceber agora que estamos aqui, com o espectáculo que estamos a fazer - que a nossa vinda para cá, a intuição desta vinda para cá está completamente ajustada a uma coisa muito maior. Desta vez acho que é ainda maior do que foi em 1992. Muito maior, que implica muito mais coisas. Toca em pontos muito maiores. Toca na questão da cidade, da centralidade dos territórios como um projecto artístico, como as ligações, as questões urbanísticas, as questões sociais, as questões artísticas. A questão da música, a dança. Nos adolescentes, nas crianças. A consequência que isto vai ter, de facto, nem eu... Eu consigo intuir - não tenho qualquer dúvida - que isto vai ter uma consequência muito, muito grande e importante. Muito maior do que a obra artística. E neste momento não tenho qualquer dúvida em relação a isso, tenho a certeza absoluta.

Eu tenho essa percepção também. Quando li o projecto - descrição e apresentação -, de facto achei que era... Não há muitas palavras para explicar. Não é inovador, não é...

Não, não é nada disso. Nada disso.

É os caminhos que abre, as coisas que podem acontecer a partir daqui e que nós percebemos que podem vir a acontecer.

Já estão a acontecer. É que já estão a acontecer. Nós, neste momento, estamos a trabalhar com quatro meninas adolescentes, pré-adolescentes, que... Não sou propriamente mística, mas às vezes há uma percepção, há uma inteligência de que não nos apercebemos, mas que está lá e da qual só nos apercebemos anos depois. Quando pedimos um espaço à câmara, não era aquele espaço, era outro. Trabalhei sobre a Sagração da Primavera, com bailarinos de street dance. A ideia foi essa: trabalhar sobre a Sagração da Primavera, ainda com a Luna Andermatt. As coisas acabam por se ligar, assim às vezes por uns caminhos... Teve que ver com as Iluminações, quando trabalhei com a Companhia Maior e conheci a Luna, e a Luna é uma pessoa absolutamente fundamental na minha vida. Comecei a pensar a Sagração da 


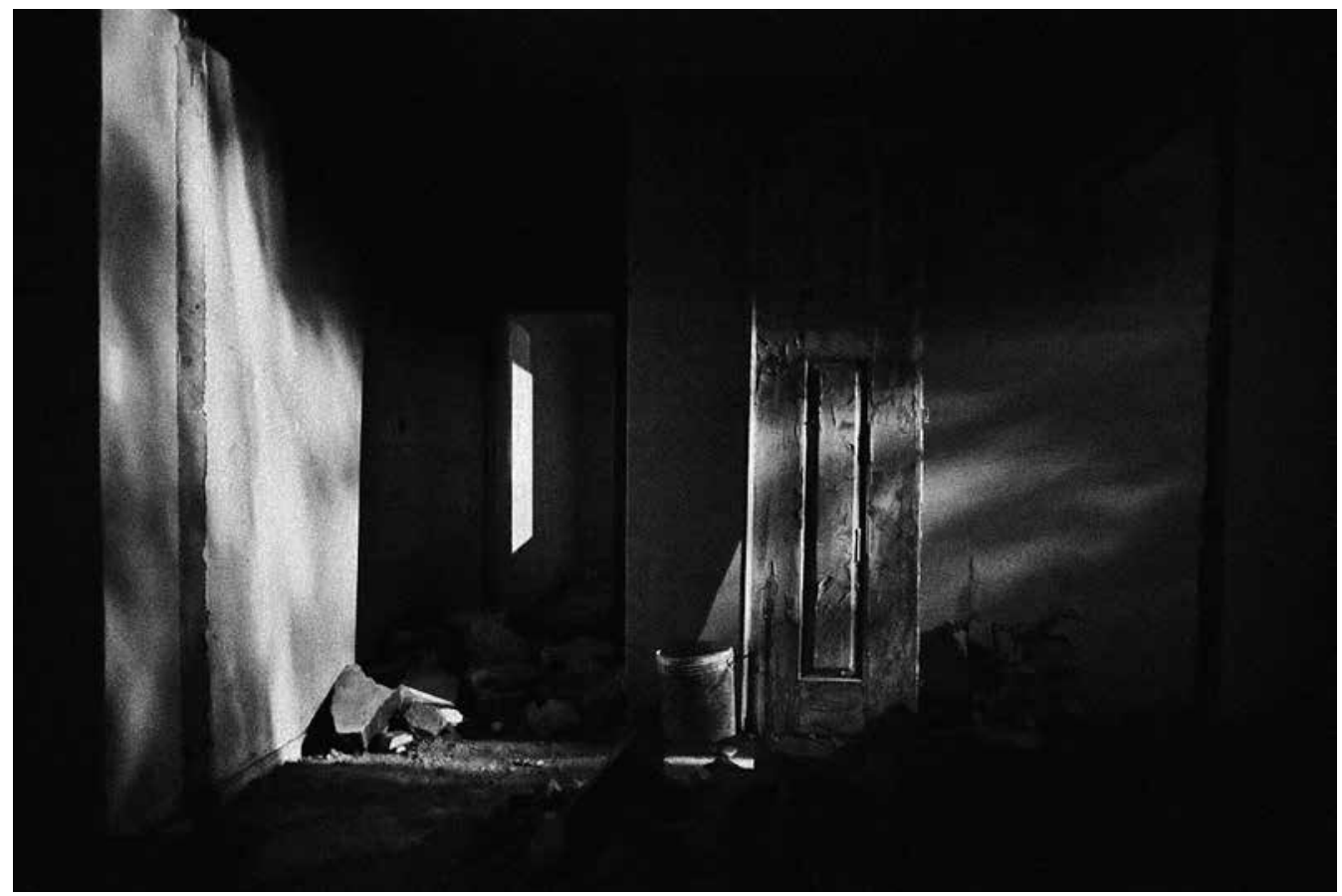

A BOA ALMA..., A PARTIR DE BERTOLT BRECHT, CASA CONVENIENTE, 2015, [F] BRUNO SIMÃO

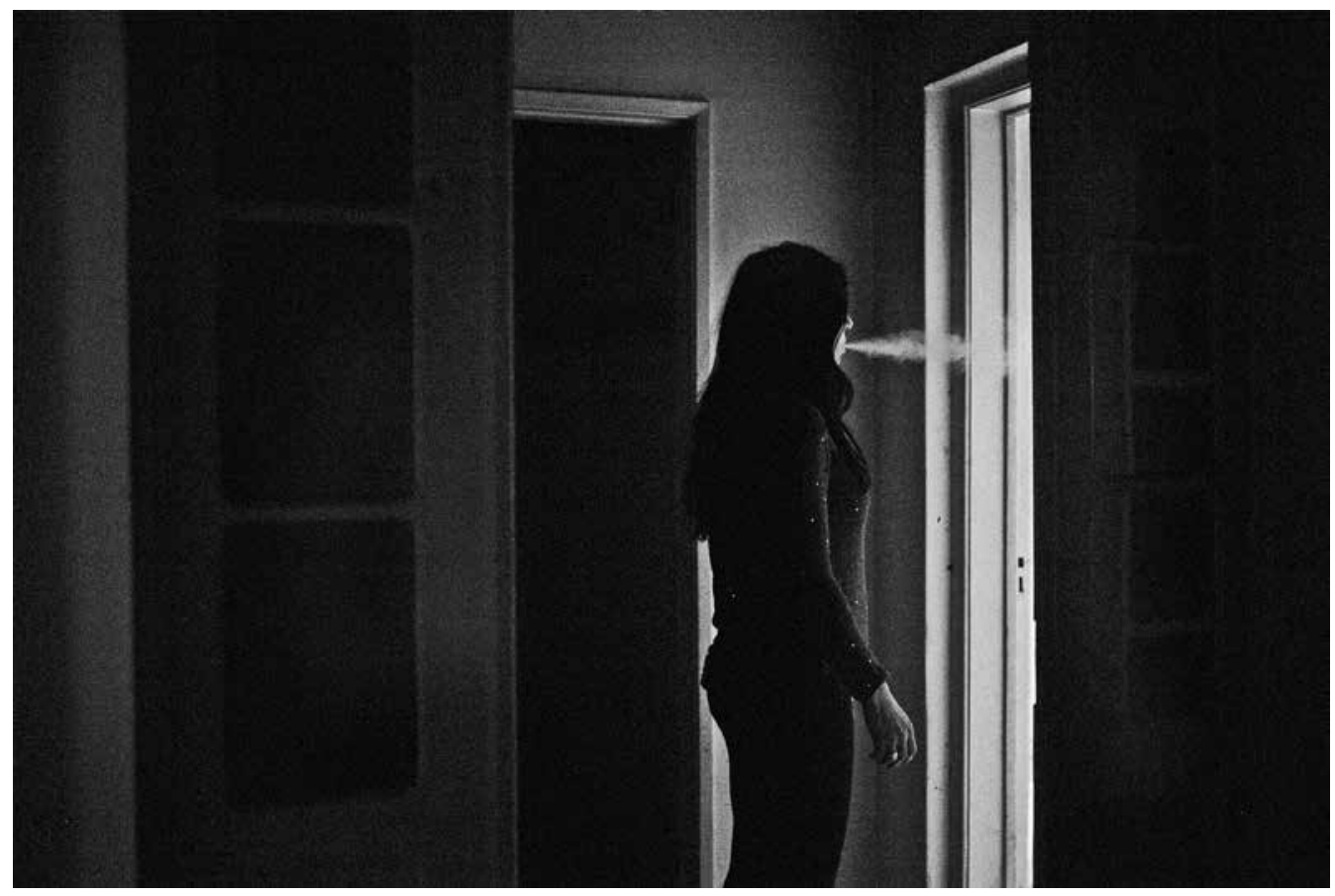

A BOA ALMA..., A PARTIR DE BERTOLT BRECHT, CASA CONVENIENTE, 2015 (MÓNICA CALLE), [F] BRUNO SIMÃO 
Primavera, e no primeiro dia de ensaios viemos aqui para a rua ensaiar, para a Zona J, e para onde é que fomos ensaiar? Exactamente para ali, para onde estamos agora - mas não sabíamos que íamos para ali - porque aquilo... não havia obras a decorrer como agora, estava protegido e era um pátio grande, um espaço aberto; o Mansinho, que é o nosso vizinho, emprestou-nos a electricidade, montámos umas colunas e estivemos ali a ensaiar. Estas quatro meninas estavam ali na rua e foram assistindo, durante aquela semana, aos ensaios. Dois anos depois, qual é o espaço que nos é atribuído? É aquele. Três anos depois, neste momento, já, essas quatro meninas que tinham oito anos, nove, agora tem onze, doze, quinze e estão a trabalhar connosco. As meninas dos gelados do Esta Noite Improvisa-se... na Zona J. Fizeram uma coreografia. Ou queriam fazer, só que já havia tanta gente, que eu não as conseguia integrar. Mas agora estão a dizer texto. Um texto dificílimo. Acontecem também coisas... Eu sei, eu sei que estão a acontecer... As pessoas também têm medo. As pessoas já sabem que há aqui um teatro. Durante estes anos todos ouvimos: «Quando é que o teatro começa?» Neste momento já sabem: «Ah, é o teatro», aquilo já é o teatro. E nós somos «os do teatro». Somos os do teatro. Mas ainda há muito medo de virem ver. Por exemplo, vamos começar a temporada em Setembro, com o Festival Zona Não Vigiada. Algumas pessoas daqui começam a vir ver os espectáculos. Passam, espreitam, mas ainda... Agora já começam a vir ver. Com este espectáculo já estamos a conseguir. Este evento da música [Festival Zona Não Vigiada] é fundamental.

A música e a dança são essenciais.

E têm um poder...

De participação e de ligação.

De ligação.

A nossa curiosidade era: como fizeram a negociação? Mas agora já percebemos tudo: é lento, é difícil, é ir embora e voltar, trazer pessoas...

E agora estamos. Agora estamos e temos várias pessoas a trabalhar: a Ana Rocha, que já está a trabalhar connosco em assistência de produção; a Andreia, que está a fazer comunicação e é daqui. Ou seja, estamos a construir uma nova equipa 
de trabalho que terá cada vez mais pessoas a entrar, não só como actores, mas também na comunicação, na construção da estrutura. Isto vai trazendo as ligações e vai construindo o trabalho. Por exemplo, a Andreia nunca tinha feito comunicação. Eu propus-lhe fazer a primeira vez. E depois acontece uma série de coisas, por exemplo, a Andreia tinha dificuldade... Dá erros ortográficos, mas ela foi percebendo e foi lendo os outros e-mails e eu tenho vindo a ver que os e-mails dela têm cada vez menos erros. O trabalho, às vezes, parece que é pequenino, mas passa por tudo. É muito, muito maior. Quando digo que tenho a certeza de que isto é muito maior do que eu até possa vislumbrar, estou absolutamente certa. Tem que ver com uma ideia de fé. Não tive propriamente uma educação católica, mas tenho fé e acho que fui percebendo o que é ter fé. Acho que nos últimos dois anos, acabei por perdê-la e, no fundo, a ideia de acreditar tem que ver com o meu trabalho. Acreditar na vida e no trabalho. No meu gesto; no gesto artístico. Continuo a achar que as coisas estão profundamente ligadas. No início d'A Boa Alma foi terrível, porque eu ainda estava nesse processo de busca. Um dos objectivos da proposta que fiz ao Luís Mário Lopes de trabalhar sobre aquele texto do Brecht era... Eu precisava, no fundo, de voltar a ter fé e voltar a encontrar-me. Em todos os meus aspectos, em todas as suas variáveis. Na relação com os outros e connosco. Foi, depois daquela violência toda e foram muitos meses, perceber. Foram muitos meses a trabalhar sobre A Boa Alma. Fiz um mês de espectáculo aqui [Zona J] e depois ainda fui fazer ao Porto, à Mala Voadora. Quando saí daqui para ir para a Mala Voadora, pensei que não conseguia fazer, «como é que eu consigo?», mas percebi que era possível e que o texto e a forma como construí o espectáculo continuava a existir e a ser compreendida, apesar da mudança de contexto. Depois fui fazer o espectáculo ao Teatro Académico Gil Vicente, com aquela plateia enorme. Estamos a falar de escalas e de relações diferentes, mas o sítio onde o texto se ligava ao público continuava a existir. A relação era exactamente igual. Quando acabou, em Abril, eu tinha chegado aquilo que eu gostaria, quando o propus. Tinha encontrado o meu lugar. Tinha recuperado essa fé. E o Festival Zona Não Vigiada também foi muito importante para este projecto. 


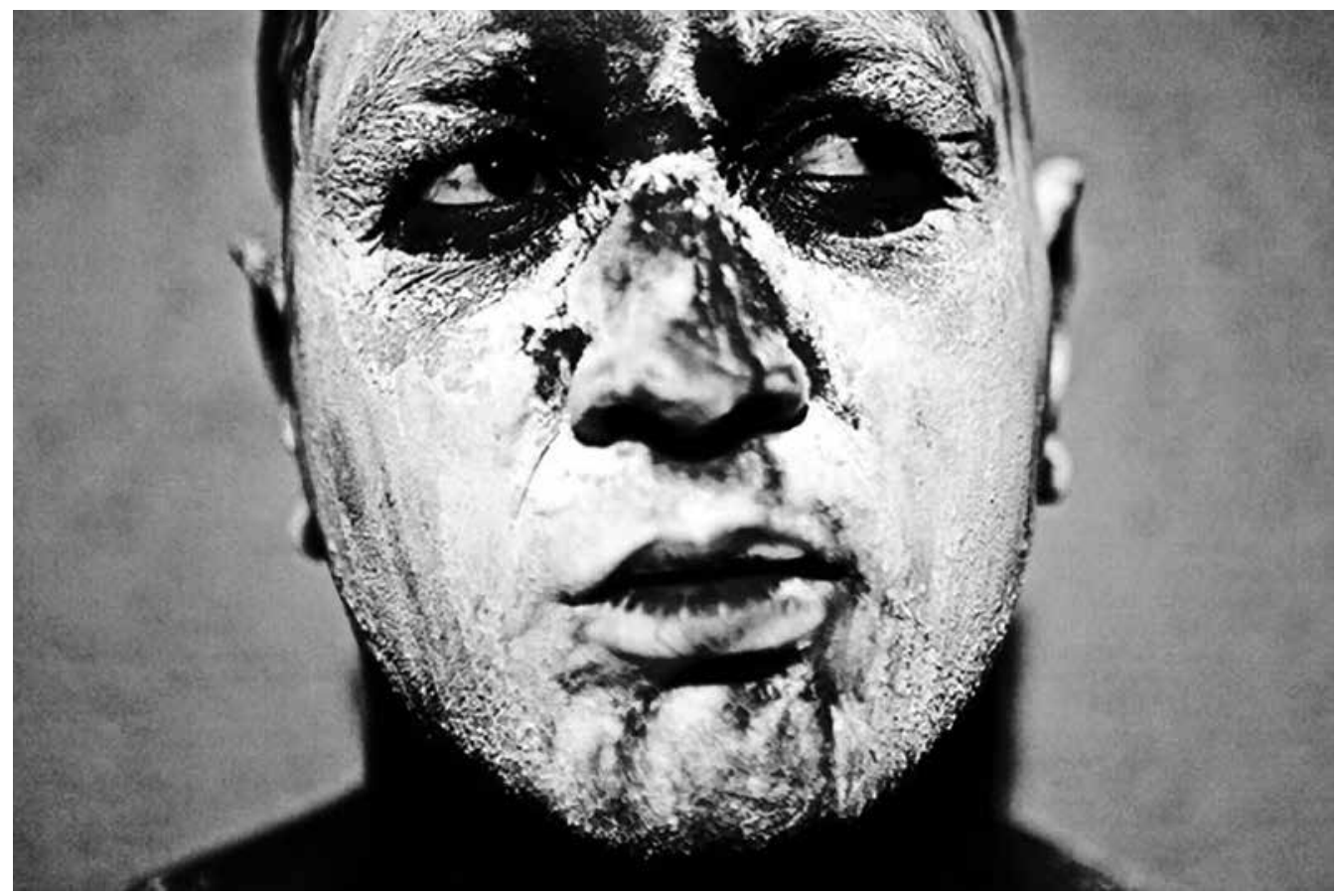

RECORDAC̣ÕES DE UMA REVOLUÇÃO, A PARTIR DE A MISSÃO, DE HEINER MÜLLER, CASA CONVENIENTE, 2011 (MÁRIO FERNANDES), [F] BRUNO SIMÃO

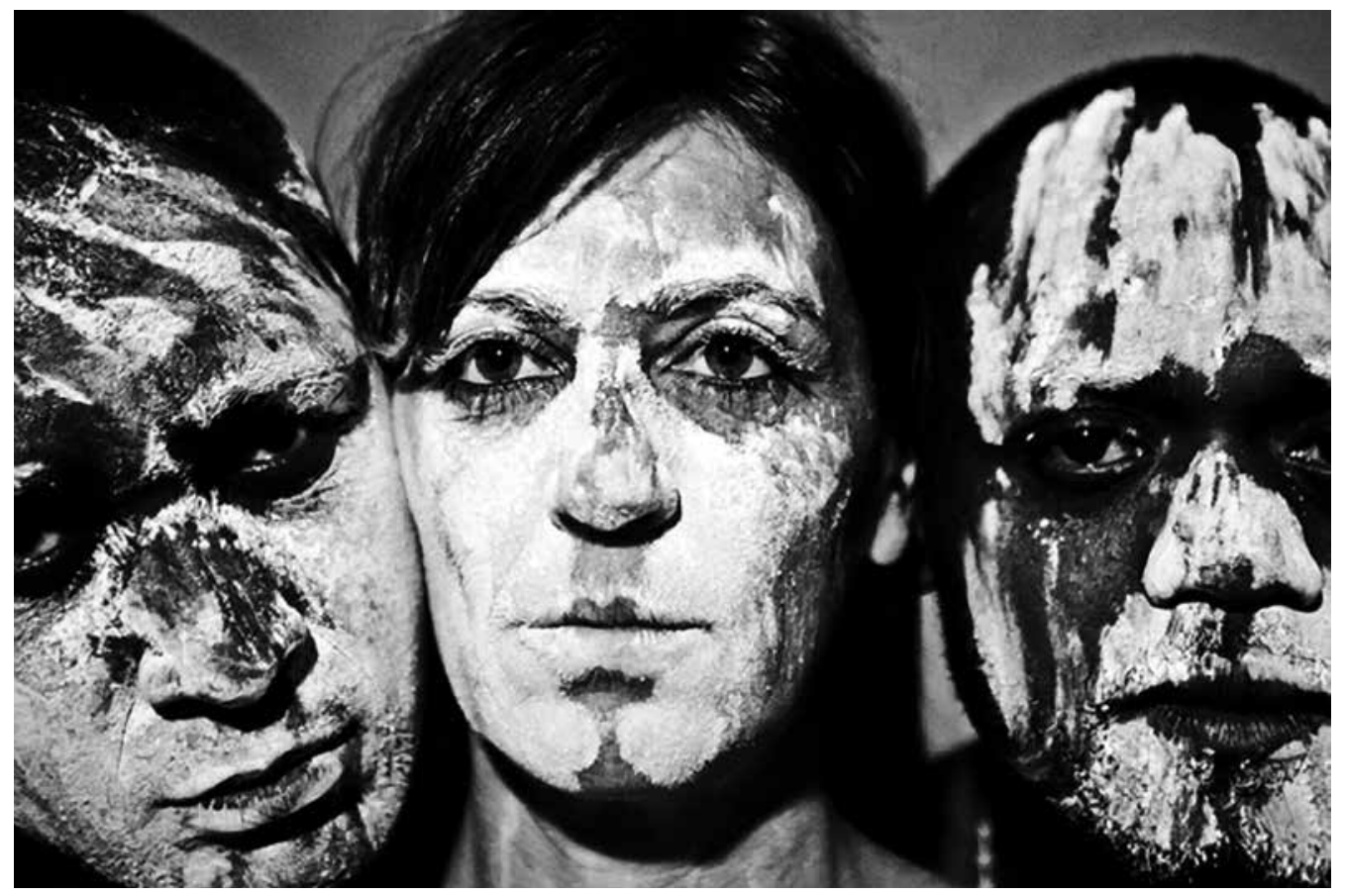

RECORDAC̣ÕES DE UMA REVOLUC̣ÃO, A PARTIR DE A MISSÃO, DE HEINER MÜLLER, CASA CONVENIENTE, 2011 (MÁRIO FERNANDES, MÓNICA CALLE, RENÉ VIDAL), [F] BRUNO SIMÃO 
Mas, no caso do Brecht, o que é surpreendente é existir um trabalho justamente em que o espectador percebe que não perdeu Brecht, mas que encontrou a Mónica Calle. Encontrou-a ali. Como é que isso aconteceu? Há um trabalho de apropriação? Foi todo o percurso através do Heiner Müller? Aquele texto apareceu como aquele onde podia ser feito esse trabalho e isso surgiu assim, com uma primeira leitura? Como é que isso acontece com os textos? Porque uma coisa é a forma tradicional, «vamos lá fazer um Shakespeare», mas a Mónica Calle não trabalha assim os textos, não é?

Mais uma vez acho que tem que ver com encontrar um texto num momento em que eu possa efectivamente ligar-me a ele. É aquele instante, é aquele momento e não poderia ser outro. Fiz dois trabalhos sobre o Brecht. Comecei pelos Sete Pecados-que também me levou a transformá-lo-e depois A Boa Alma... e sempre com este tratamento duplo, e o Brecht também... aquilo que o autor é. Quando não tive sítio, foi o Brecht que me ajudou a conseguir. Foi com o Brecht que consegui fazer o caminho. Não sei explicar. Naquele momento em que não tendo, pela primeira vez desde que comecei a trabalhar, um sítio, é o Brecht que me ajuda a fazer o caminho.

\section{Provavelmente porque ele próprio fez isso. Ele próprio andou por} todo o lado procurando continuar a fazer o seu teatro.

Não fui à procura do Brecht. Foi pensar no Müller, ou seja, na realidade, também o Müller foi um momento daqueles meses. Um contexto. $\mathrm{O}$ ciclo Heiner Müller estava programado há seis anos e eu, por qualquer razão, não o consegui realizar. Foi em 2011, quando eles saíram da prisão, que finalmente fiz o ciclo. Foi quando comecei a pensar em vir para a Zona J e depois, no momento em que ainda estava à espera, em que estava a fazer o caminho, aparece o Brecht e é com ele que o consigo fazer. O Brecht tem esta possibilidade de uma coisa que é nova no meu trabalho, que tem que ver com a música, com o coral, com a comunidade, com a questão social, com a questão individual. O indivíduo e o todo. Eu, que nunca tinha olhado para o Brecht... Primeiro, eu chego ao Brecht, mesmo que não saiba, por ter trabalhado com o Müller. Era impossível eu não ir ter com o Brecht naquele momento, naquele contexto...

O Brecht é um autor com que não se sabe já trabalhar?

Sinto que antes não fazia sentido; nunca fez sentido pegar no Brecht. Neste momento, o Brecht é provavelmente dos autores que 
me permite mais liberdade. $E$ vou continuar com o teatro que ele propõe. Questionando, duvidando, fazendo, relendo. Mas a partir dele. Não tenho qualquer dúvida de que o texto do Luís Mário Lopes é Brecht. Está profundamente lá. Müller trabalhou Brecht de uma maneira muito particular. Mauser e A Decisão são textos tão... Ou seja, Mauser é uma transformação d'A Decisão.

\section{É ler, reler e construir por cima.}

Ler e construir por cima, mas estando lá. Acho que de alguma maneira os meus encontros com os textos foram... são todos assim. Por isso é que não sinto uma necessidade de procurar autores. Preciso também de um tempo, de ir trabalhando. De descobrir, de trabalhar, de voltar a ler. Por exemplo, quando começámos a trabalhar em Vale de Judeus. Trabalho sempre sobre o texto escrito. Desde o primeiro dia. Não consigo trabalhar sem um texto escrito. No segundo dia em que trabalhei com eles [em Vale de Judeus], levei uma série de livros de que gosto: À Espera de Godot, Pirandello... Vou sempre carregada com um monte de livros e fui à procura. Na altura, o Silva Melo tinha editado, nos livrinhos de bolso, Breves Textos para a Liberdade, que são peças curtas, mas que são muito direccionadas. No terceiro dia em que trabalhei com eles, distribuí vários textos assim... «agora fazes isto, tens 15 minutos para ler e vamos improvisar», sempre sobre a palavra. Os grupos tinham ficado com os Breves Textos para a Liberdade, que eram muito directos e abordavam contextos prisionais, de opressão, mas não fazia sentido nenhum. Toda a gente fez. Curiosamente, havia dois actores que ficaram com um bocadinho que lhes dei, três páginas, do À Espera de Godot e foi incrível. Incrível como eles improvisaram a ler. Alguns com muita dificuldade em ler, atenção. Nunca tinham feito isto, portanto, com muita dificuldade. Foi incrível como eles perceberam automaticamente o texto. Três páginas e toda a gente percebeu. Pensei assim: «Não, já percebi, é com isto que vou trabalhar. É isto que vou trabalhar.»Depois o que fiz foi: eles eram quinze actores. A Mónica e a Rita começaram logo a trabalhar comigo. Também eram actrizes. O que fiz foi partilhar as vozes. Não havia propriamente o Didi e o Gogo, mas eram todos Didis e Gogos. Não havia a ideia de personagem. No fundo, era o texto, era a palavra. Era o que estava a ser dito e partilhado. Era a voz de todos. Todos eram todos. Maria João, 
a forma como aquele texto ecoa dentro de uma prisão... Muitas vezes acho, por exemplo, em relação a Beckett que se comete um grande equívoco. As pessoas acham que o Beckett é muito abstracto e perdem-se no ritmo, nas palavras.

Acham que é abstracto e sem sentido.

Não é nada. Beckett é absolutamente concreto. Aquele texto parecia ter sido escrito para ali, para aquele contexto. Não havia uma palavra, uma frase que não tivesse uma relação directa e concreta com tudo: com a situação de prisão, de falta de esperança, de culpa. Por exemplo, nunca faço trabalho de mesa. Nunca ponho os actores sentados a falar sobre os textos. Dou-lhes os textos e eles começam - mesmo que estejam em pé - a ler o texto, a ter uma entoação, e nós vamos falando sobre o texto à medida que avançamos. Portanto, não determino o que aquele texto quer dizer. Não digo o que acho que é o texto. Acredito que os textos falam.

Que falam e que lhes vão dizer o que têm a dizer.

Essa relação é individual. Digo isto a todos os actores: acreditem. Acreditem no que o texto diz. As palavras estão lá, é só acreditarem. É deixarem. Elas falam. Ouçam. E existam nelas.

Como entram os actores nisso? Têm de entrar através das palavras?

É acreditar nas palavras. Porque aquelas palavras, sendo orais, são ditas por alguém, só existem se... O texto decorado e dito depois é para fora, não é para dentro. Há uma relação que tem que ver com a oralidade. $O$ texto não pode existir plenamente se também quem é o veículo não o fizer. $O$ texto só pode existir se o intérprete existir profundamente, secretamente, mas naquilo.

Lemos uma frase sua que dizia que o actor precisa de acreditar em si. Acreditar em si naquele momento. Portanto, acreditar não do ponto de vista intelectual...

Não, não. Acreditar e ser e existir e compreender. É essa a grande liberdade do gesto criativo. Essa é a nossa liberdade. Existir.

Existir profundamente e secretamente. Permitir-se descobrir-se. Descobrir-se através disso. No contexto prisional, ter feito Beckett, À Espera de Godot, que é um texto sobre o qual já trabalhei algumas vezes, foi completamente surpreendente. Descobri novamente 
o texto. Isso é das coisas mais extraordinárias de um bom texto. A palavra escrita. Essa capacidade de, no fundo, dialogar permanentemente connosco e...

Estar sempre ali para o descobrirmos.

Sempre. Continuo a ficar deslumbrada quando um texto me volta a... surpreender.

Isso aconteceu com o Rimbaud?

Sim. O Rimbaud também é um autor, para mim, particularmente querido. Em especial Uma Cerveja no Inferno... Voltei a fazer A Virgem Doida em 2012, exactamente quando aquilo rebenta tudo: quando acaba a Casa Conveniente no Cais do Sodré, quando falha a candidatura, tudo... Aliás, acho que esta ruptura toda e ter sido tão violenta e radical... só percebi depois. Na altura não me apercebi. Voltei a pegar no Rimbaud. Em 1992 só fiz A Virgem Doida, só um dos textos. Vinte anos depois já não era possível fazer só aquilo. Não era suficiente e já não fazia sentido. Eu era outra pessoa, o contexto era outro. Para mim, de repente, fez sentido fazer toda Uma Cerveja no Inferno; todo o percurso. Aquilo é um caminho. É uma descida ao inferno, que é simultaneamente um recomeço. No fundo, o primeiro texto é já pós-descida. Percebi que, quando fiz Uma Cerveja no Inferno em 2012, aqueles três anos tinham sido realmente a minha descida ao inferno. Fiz o caminho que o Rimbaud fez. Percebi também que já tinha regressado, porque o texto me surpreendeu. Não tinha lido aquela obra assim um ano antes. Foi exactamente o primeiro texto que me comoveu. Só percebi isso quando fiz o espectáculo. Já tinha feito a minha descida. É isto, afinal é isto. O que estou a fazer, tudo o que aconteceu naquele ano e meio... tudo o que vem aí foi na realidade aquela descida ao inferno... Inclusive a perda de fé e o recuperar. Aquilo tem uma coisa, no primeiro texto, em que ele diz: «Caridade - É a chave.»

Como é essa relação, a construção dessa relação de proximidade com o espectador, que imagino mais difícil de concretizar em salas como o Teatro Académico Gil Vicente ou a Culturgest? Como é isso pensado do ponto de vista da exposição do corpo do actor na situação, no 


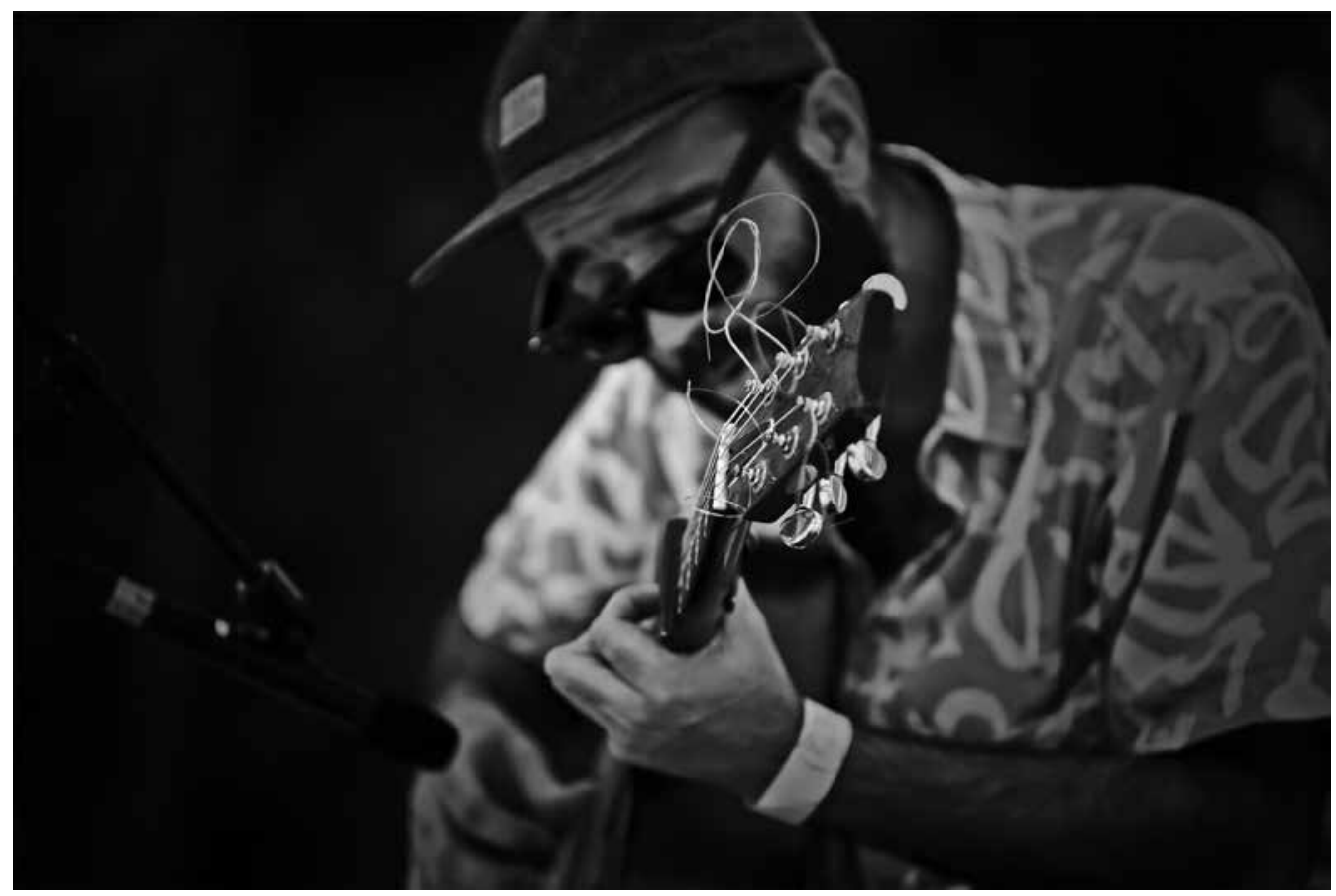

FESTIVAL ZONA NÃO VIGIADA, CASA CONVENIENTE, 2015 (NORBERTO LOBO), [F] BRUNO SIMÃO

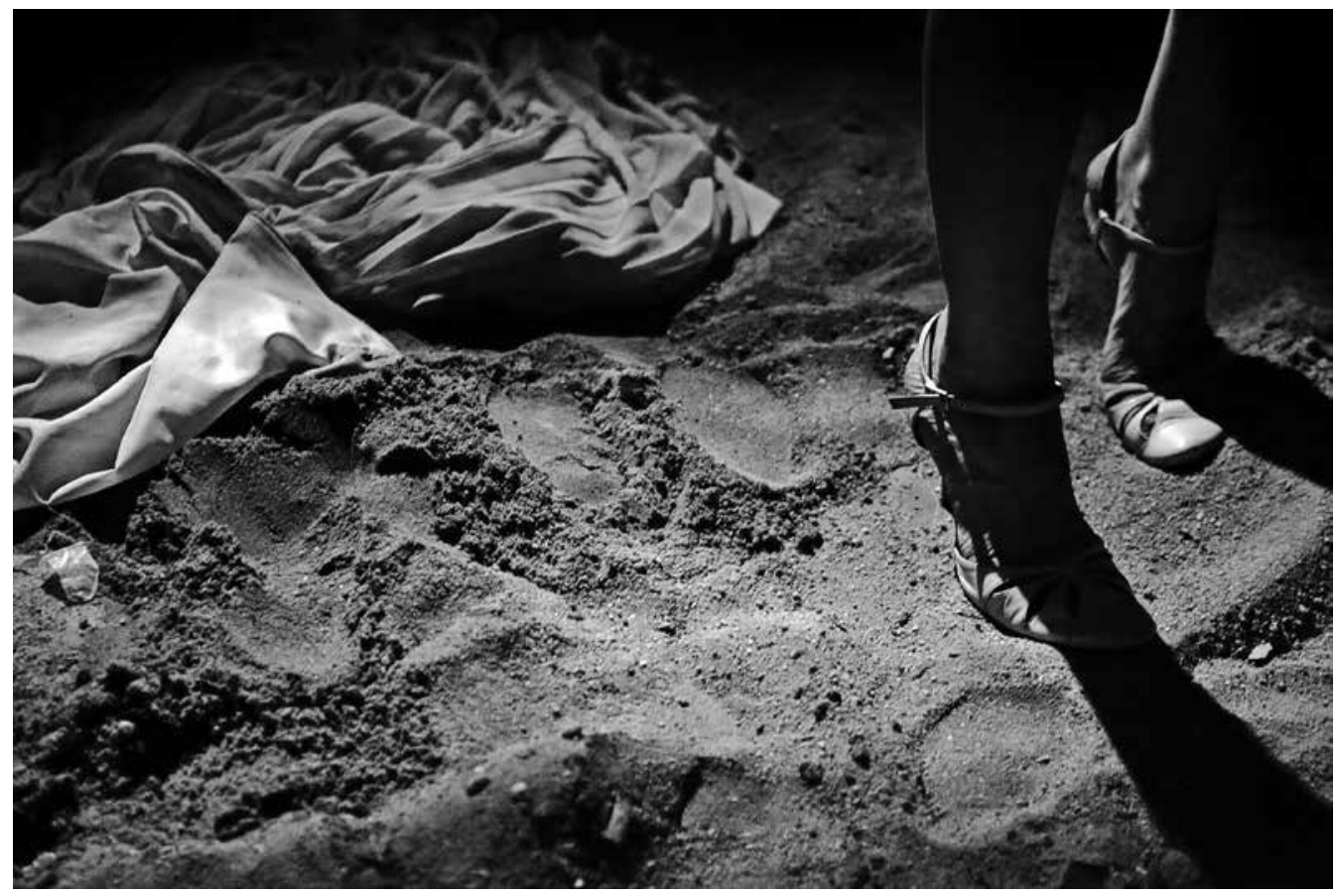

A VIRGEM DOIDA, A PARTIR DE RIMBAUD, CASA CONVENIENTE, 2012 (MÓNICA CALLE), [F] DE ENSAIO BRUNO SIMÃO 
momento, naquele momento? Naquele momento um pouco fora do tempo também, não é? Também já falou disso noutros textos que vimos, esse tempo fora do tempo. Que corpo é esse? É um corpo que se vai construindo também com a palavra?

Sim, é um corpo que se vai construindo e que tem sempre que ver com a palavra. Para mim, a construção sempre começa com a palavra. Sempre, sempre. Trabalho muito sobre a fisicalidade e sobre a dureza. Muitas vezes são estratégias que encontro para a palavra poder existir. Acredito que a violência física, ou o esforço físico, obriga os actores e intérpretes a concentrarem-se nesse esforço e a deixar de pensar. Portanto, permite-me trabalhar a procura de verdade. Deixa de haver barreiras racionais e a possibilidade de se...

Encontrar defesas, de criar...

Há sempre. Mas são sempre de alguma forma estratégias. Ao mesmo tempo tem que ver com uma ideia de generosidade. Acho que, por exemplo, na música isso se sente. Há uma série de palavra, emoção, razão, concentração, porque é preciso as coisas estarem todas ligadas. Há muitas coisas que têm de estar em simultâneo, mas ao mesmo tempo tem de haver essa generosidade, que tem que ver com isso: o intérprete, no fundo, é um vínculo e um bocadinho um alquimista. É um alquimista, com o seu corpo, com a sua vida, com a sua individualidade e particularidade física e emocional e mental.

Transformar o que passa por ele.

Transformar, existir e permitir que os espectadores entrem também nesse sítio. É como se o movimento também só acontecesse se houver essa generosidade que é permitir - e não impor - que os outros possam estar também nessa relação com as palavras, com o corpo, com a emoção. Acredito que é um movimento assim [gesto sugerindo entrada e saída do corpo], não te consigo explicar isto de outra maneira.

Dizes então que o teu trabalho sobre o corpo é também uma forma de criar empatia com os próprios corpos do público?

Sim, e de oferta. É um bocadinho como um... Eu vou pegar nisto, porque penso nisso. Quando foi Os Meus Sentimentos, aquele início do espectáculo que algumas pessoas não... Também foi tudo uma coisa, para mim, muito surpreendente que aconteceu, aquela ideia 


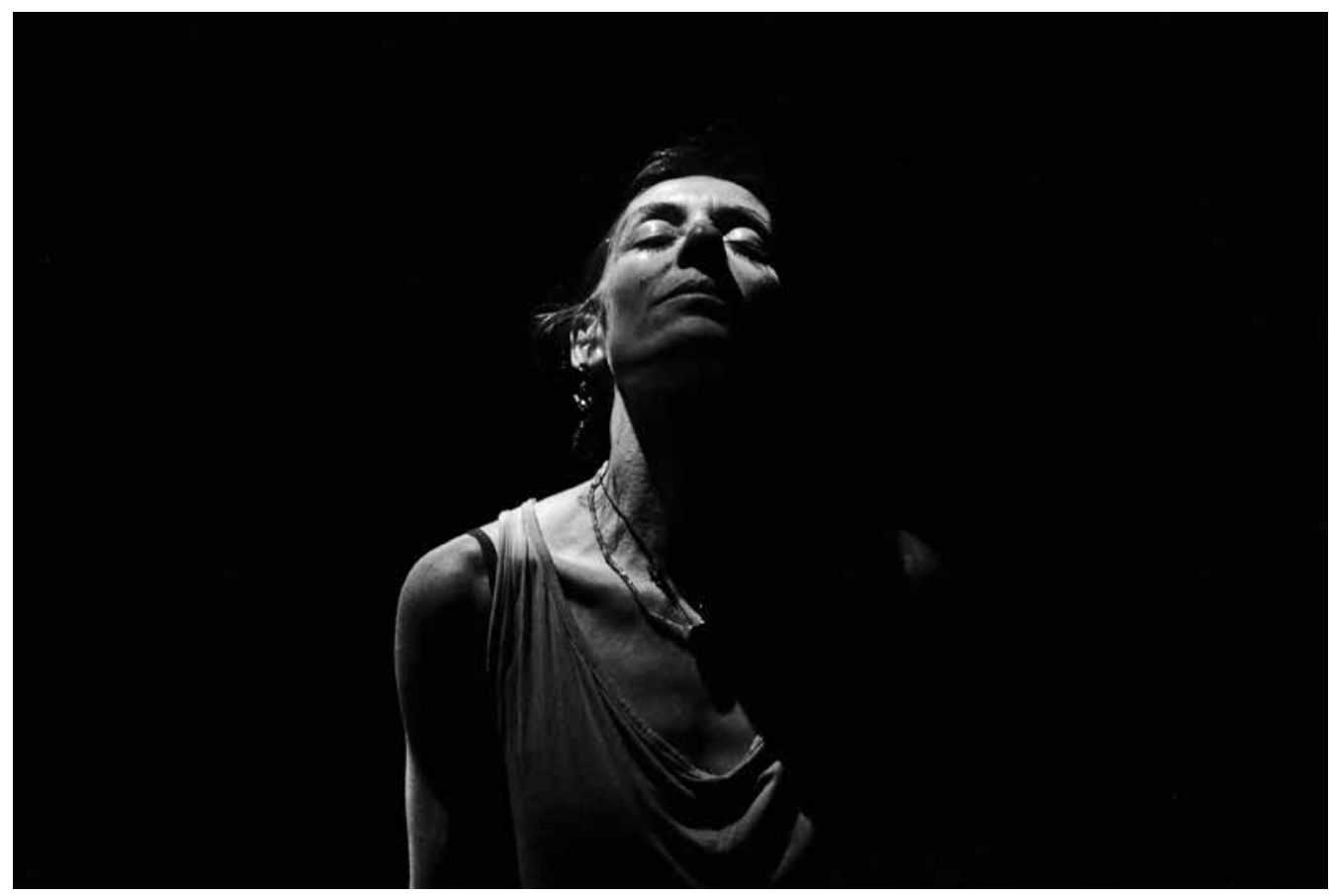

OS MEUS SENTIMENTOS, DE DULCE MARIA CARDOSO, CASA CONVENIENTE/CULTURGEST, 2013 (MÓNICA CALLE), [F] BRUNO SIMÃO

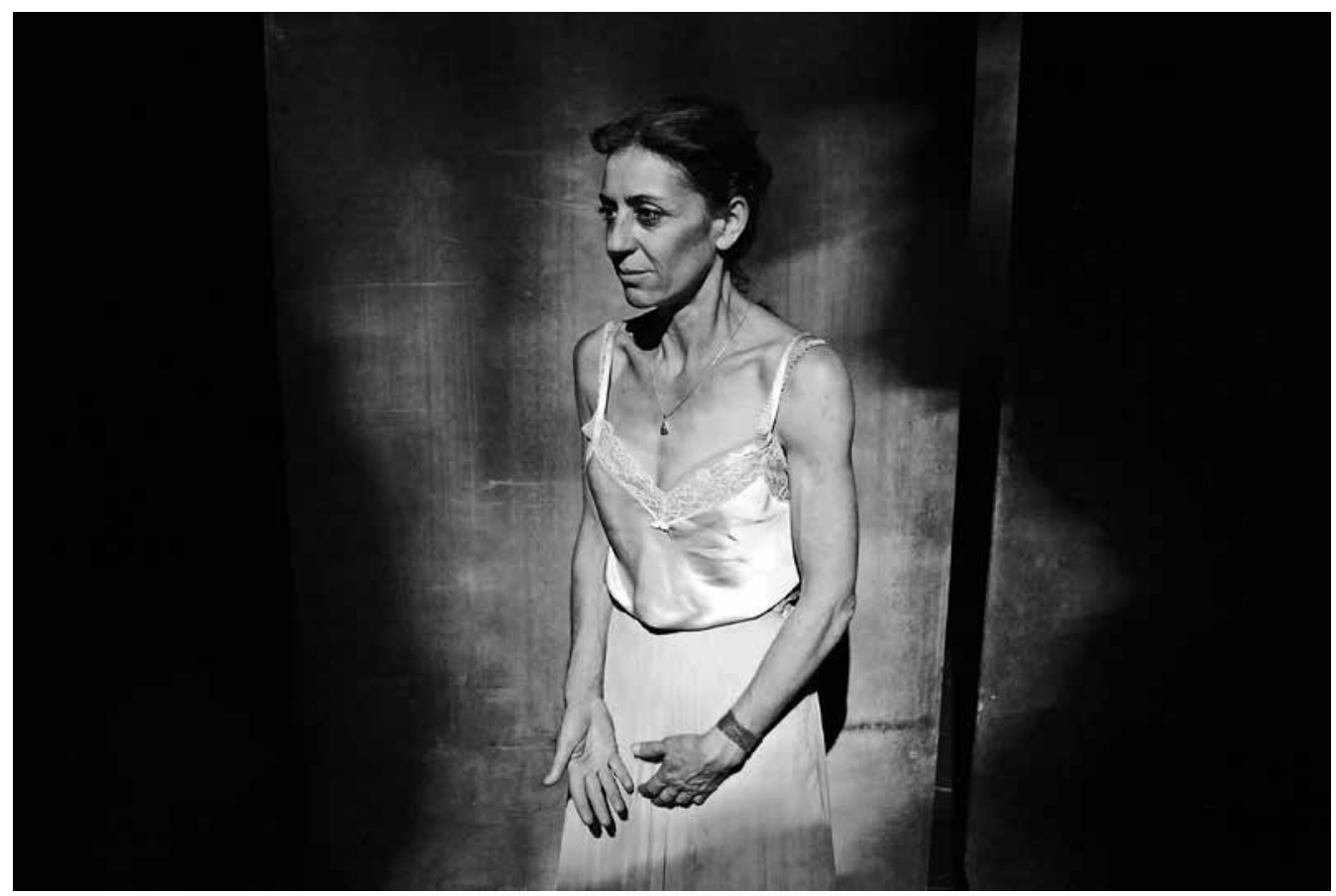

A VIRGEM DOIDA, A PARTIR DE RIMBAUD, CASA CONVENIENTE, 2012 (MÓNICA CALLE), [F] DE ENSAIO BRUNO SIMÃO 


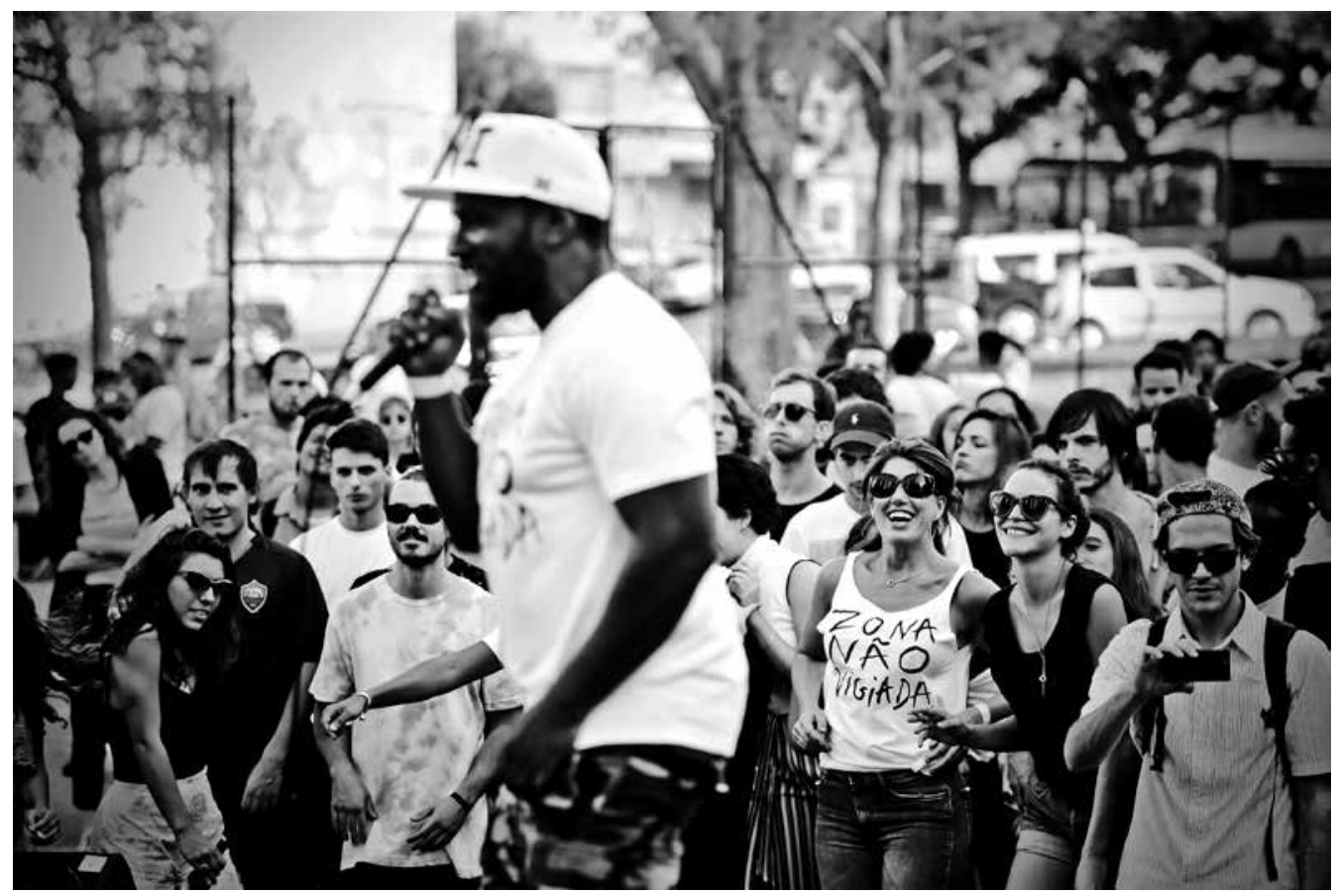

FESTIVAL ZONA NÃO VIGIADA, CASA CONVENIENTE, 2015 (NEWHAM GENERALS), [F] BRUNO SIMÃO

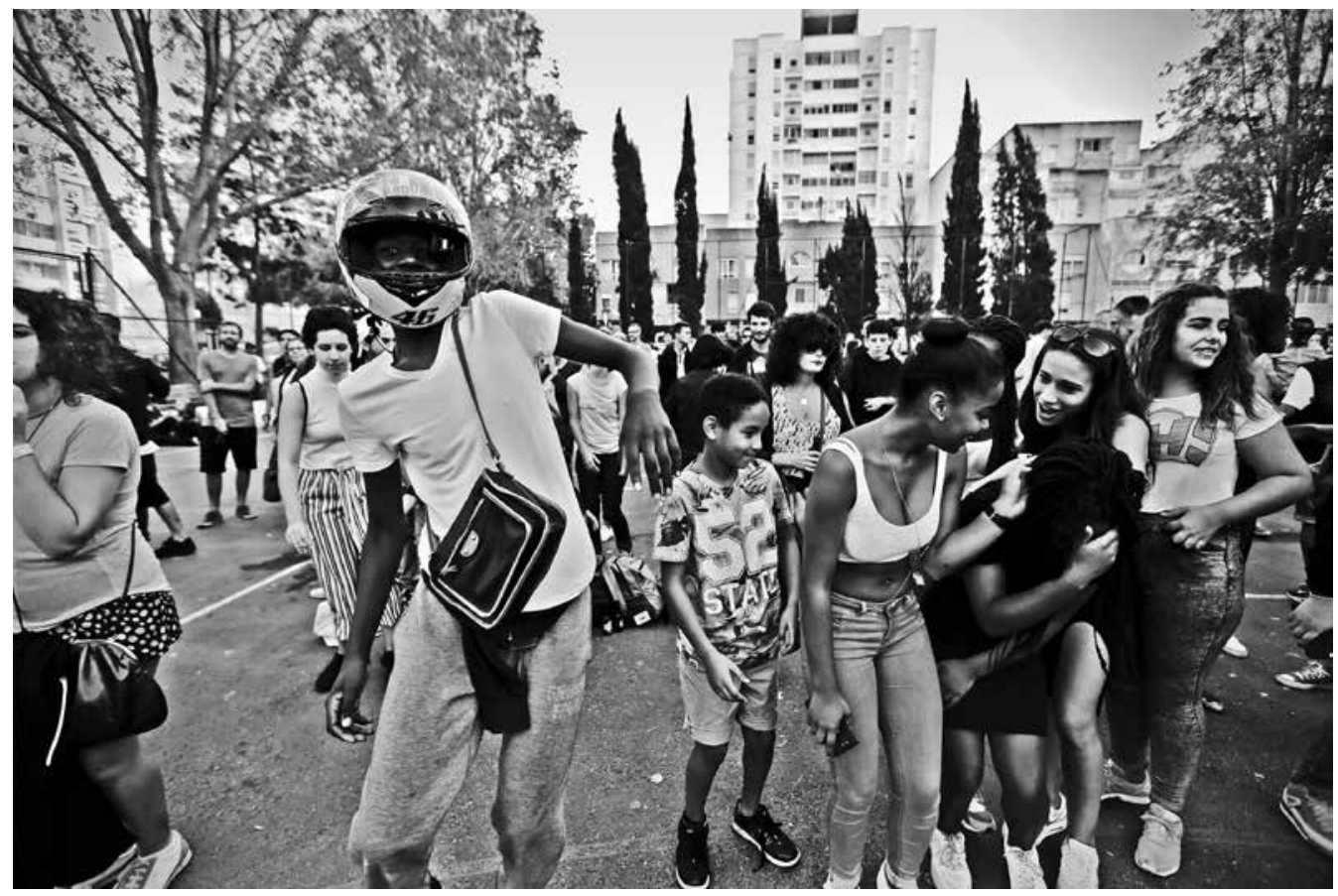

FESTIVAL ZONA NÃO VIGIADA, CASA CONVENIENTE, 2015, [F] BRUNO SIMÃO 
de... Ou seja, eu começava com uma oração e não foi premeditada, não foi... Aconteceu-me, no dia da estreia, estava assim numa circunstância muito particular e aconteceu-me uma coisa que nunca me tinha acontecido na vida: sentei-me no sofá e estava estourada, por várias razões da minha vida particular... Sentei-me a ler o texto às três da tarde e adormeci. Adormeci. Acordei às 19.30, que era quando o espectáculo começava... Foi a sensação mais terrível da minha vida e fui a correr para a Culturgest. O que disse foi a verdade. Eu sei que as pessoas têm muita dificuldade em acreditar. As pessoas não acreditaram quando eu disse, antes de começar: «Desculpem, obrigada, estou muito cansada e sentei-me no sofá a ler o texto e...» a chorar, obviamente. Podia não ter dito isto. Podia ter dito que tinha acontecido um problema técnico, podia não ter dito nada. E depois, naquele momento, não sabia se ia conseguir fazer o espectáculo ou não... Pensei: preciso de uma oração. E pedi ajuda, porque não sei rezar. E isto é mesmo verdade, não sei. Portanto, pedi a alguém que me ajudasse a fazer uma oração e foi isso que me permitiu ir com aquele espectáculo para a frente. Fiz aquilo que tinha pensado e que começava com a ideia da masturbação. Não era uma ideia voyeurista. Tinha mesmo que ver com a ideia de ser real. Era de verdade. Não mostrava nada, não era visto. Estava em pé. Tinha que ver com uma ideia cristã que é isto de que estamos a falar, do corpo, por isso é que estou a falar nisto. Tem que ver com a ideia daquilo que para mim o cristianismo significa e a figura de Cristo. Tudo isto é palavra e corpo. A vida. E acho que de todas as religiões monoteístas é aquela que é no fundo a mais completa nesse sentido, porque não há separação entre corpo e alma, entre palavra e... ou seja, Cristo é exactamente a concretização.

\section{A palavra feita corpo.}

A palavra feita corpo. E a aceitação que é: este é o meu corpo. Comei e bebei. É isso que peço. É isso em que acredito em relação ao corpo do intérprete: este é o meu corpo... é assim que trabalho sobre o corpo.

Lemos algures que a Mónica esteve ou participou num trabalho do Kantor. É verdade, e algumas dessas coisas vêm até ao seu trabalho?

Sim, é verdade. Vêm, muito. Mas, mais uma vez, só percebi como o Kantor tinha sido importante e tão determinante no meu trabalho muitos anos depois. Foi absolutamente determinante em inúmeras coisas. 
A questão do intérprete, que referia... do seu esgotamento?

Sim.

E a questão da verdade, não é?

Sim.

O presente pleno e cheio?

Sim. Na altura, eu estava no Conservatório. Estava no segundo ano - o ano em que veio cá o Kantor, a Pina Bausch pela primeira vez, e o António Pinto Ribeiro falou com algumas pessoas da Escola Superior de Teatro e Cinema e da Escola Superior de Dança, para fazerem o acompanhamento. Ele quis que tivéssemos oportunidade de estar lá dentro. Fiz tudo: assistência de produção, assistência não sei de quê, eu ia buscá-los, eu... Eles estiveram bastante tempo cá, ainda numa época em que as estruturas vinham quinze dias para trabalhar antes de apresentar um espectáculo. Já não é possível, mas era. Eles vieram quinze dias antes para trabalhar e apresentar no local. Portanto, estive quinze dias com eles de manhã à noite. Ia buscá-los ao hotel, ia almoçar com eles. Conversar com eles. A ver o Kantor trabalhar; duríssimo. Terrível, terrível. Muito exigente. De uma exigência e um rigor impressionantes.

Isso passa para o espectador, essa exigência.

Durante aqueles dias todos, ele começou a falar-me, a dizer só boa tarde. Ele dizer isto era assim... Porque ele, às vezes, nem sequer cumprimentava os actores. Mas foi impressionante e foi um espectáculo muito bonito, porque foi o último espectáculo que fez e ele sabia que ia morrer. Aquilo é uma carta de despedida. Je ne reviendrais jamais. Só me apercebi da forma como aquele espectáculo me tinha marcado quando fui à procura disso, muitos anos depois. Tenho o programa, o guião. O texto é lindíssimo. Já o usei até várias vezes. A Luna Andermatt, quando fez as Iluminações, dei-lhe aquele texto e disse-lhe: «Luna, gostava que dissesse este texto. Faça uma montagem sua.» Ela dizia a parte que ela escolheu desse texto de Kantor. Só para dizer que isto é uma coisa tremendamente importante. Tenho uma dedicatória do Kantor, um agradecimento e uma série de palavras que ele me escreveu no guião. 
Retomando a questão do corpo, que também tem que ver com esta questão de viver o presente e desse comprometimento com o presente. Acho que já disseste numa entrevista anterior que, quando expões o teu corpo - essa dádiva, essa disponibilidade -, estás a construir também um corpo público. Como achas que o público te vê? Sentes que tens uma imagem colada? E isso é uma coisa que também te interessa manipular ou explorar?

Não... Vamos ver se consigo explicar isto. Quando fiz a segunda Virgem Doida em 2012, uma das grandes questões que me fiz - e foi muito violento fazê-lo, porque era uma questão importante para mim - tinha que ver com o envelhecimento do meu corpo. Ou seja, quando fiz $A$ Virgem Doida tinha 25 anos e obviamente que tinha o corpo de uma rapariga de 25 anos. Aquilo que quis fazer com A Virgem Doida era exactamente brincar com a ideia de cliché, mas em relação à fisicalidade do corpo. Trabalhar no sentido contrário. Ou seja, que um corpo nu não tem que ver com o erotismo. Eu não trabalho nunca sobre erotismo. É exactamente o contrário, tem que ver com o corpo real. O corpo individual e real. No fundo, tem que ver com a vitalidade. A pulsão vital. Tem que ver com a vida. Mas é claro que o meu corpo tem... Eu estou a envelhecer. Ao fazer A Virgem Doida e ao confrontar-me com esse dilema. Obviamente que sei fazer luzes... Posso expor-me ou não me expor. Eu exponho o meu corpo como quero; sei fazê-lo. Sei protegê-lo e sei expô-lo, e nesta segunda Virgem Doida eu começava com uma luz que fiz propositadamente e foi violentíssimo para mim. Obviamente que isso colocou muitas questões: neste momento, nesta idade o meu corpo é este. Já tive três filhos, tenho quarenta e cinco anos. Tenho um corpo que tem uma vida, uma carga, mas é este o meu corpo. Eu precisava de resolver essa questão. Também tinha que ver com saber que a perspectiva da menopausa era uma coisa que me angustiava imenso. Não é que quisesse ter mais filhos, mas a minha sexualidade, de alguma forma, sempre esteve ligada a uma ideia de ter filhos. A sexualidade tem que ver com essa possibilidade. E, portanto, para mim, era... «e agora, o que vai acontecer? Como é que...? O que é isto?» Foram questões que me foram angustiando. Isso existiu no meu trabalho. Esse confronto também existiu. Por exemplo, ter-me confrontado física e publicamente com esse meu corpo que tem a idade que tem, que tem uma história... É o meu corpo, é este. Tem esta idade e tem esta carga. Isso ficou resolvido. Neste momento, estou na menopausa e de repente percebi que afinal não há nenhuma questão. Mesmo a questão da dança, de trabalhar, 
com esta vinda para cá, com pessoas mais novas, também está a fazer uma coisa que é...

A diferença é cada vez maior.

E isso reposiciona-nos imediatamente.

Sim, mas isso voltou a ser bom. Nunca tínhamos trabalhado com adolescentes e pré-adolescentes. Se calhar só consigo agora, que estou mais velha. Há alguma novidade...

... uma disponibilidade...

E eu tenho maturidade e acho que tenho uma capacidade, neste momento, de conseguir trabalhar com pessoas mais novas.

Acho mesmo que tem que ver também com a idade, com a minha experiência. A distância que já é possível.

A palavra não é bem transmissão, mas estar a trabalhar com esses jovens, os jovens de Vale de Judeus e as pessoas daqui, os que vêm da Escola de Teatro... não significa passar uma experiência?

Há seis anos, houve assim uma série de pessoas que começaram a trabalhar comigo pontualmente, a Dina, a Inês Vaz, a Sofia, a Joana de Verona, o Zé Vitorino, a partir dos workshops, com este modelo de trabalhar...

E esse modelo não parece pensado para obter um resultado, mas para o quê?...

É um processo que acaba por criar ligações de cumplicidade que tem vindo a acontecer... Por exemplo, agora, neste workshop, houve muita gente que está no Conservatório. Está a haver outra geração de pessoas que se está a interessar pelo meu trabalho. Pessoas novas, que querem trabalhar comigo, que querem vir ver.

Que querem conhecer estando por dentro.

Que querem conhecer e de repente se ligam. Estão ligadas ao meu trabalho. A estes últimos trabalhos. Houve momentos em que isso não aconteceu. Há momentos em que estamos em sintonia, outros em que não estamos, mesmo sendo o nosso trabalho o mesmo. 


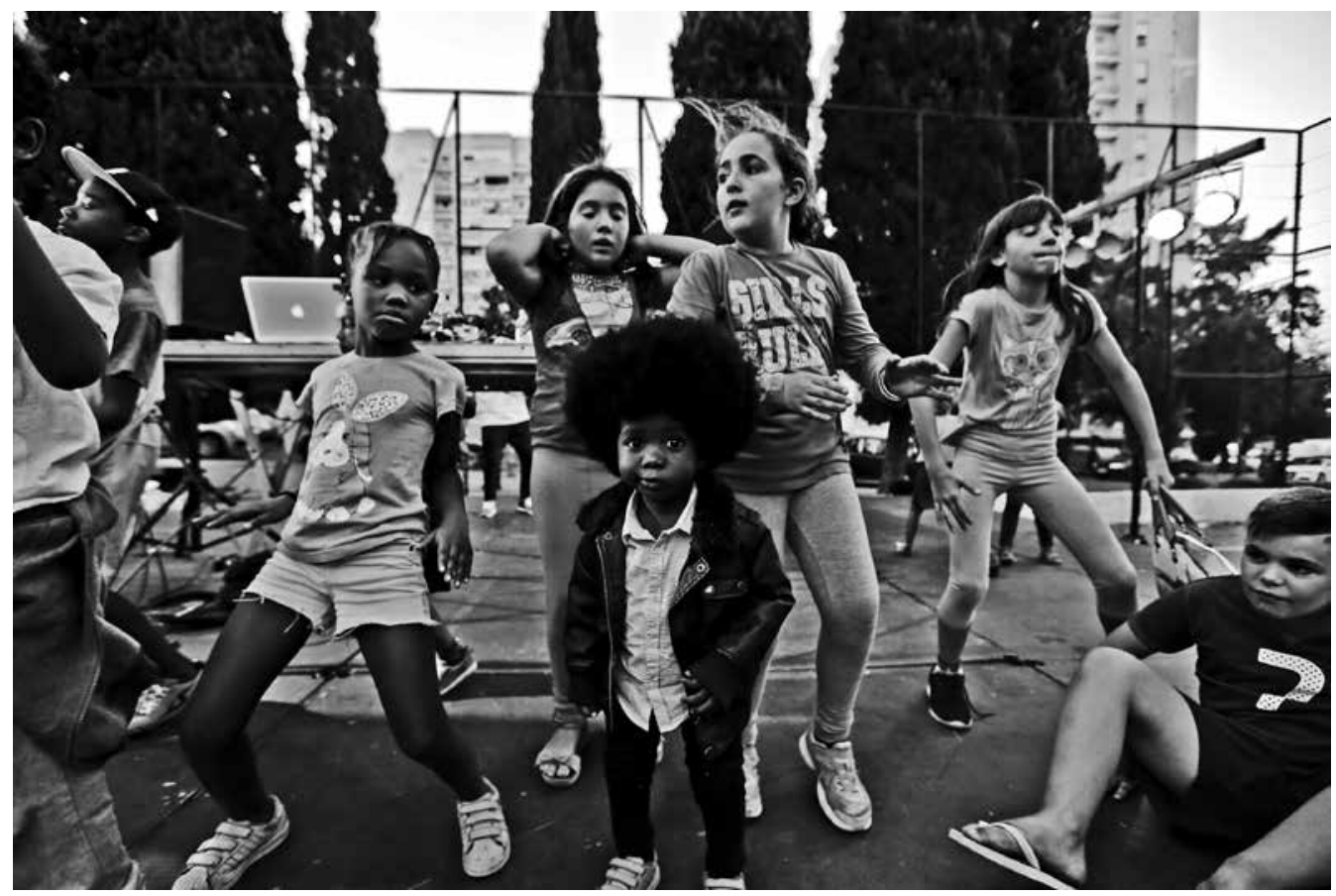

FESTIVAL ZONA NÃO VIGIADA, CASA CONVENIENTE, 2015, [F] BRUNO SIMÃO

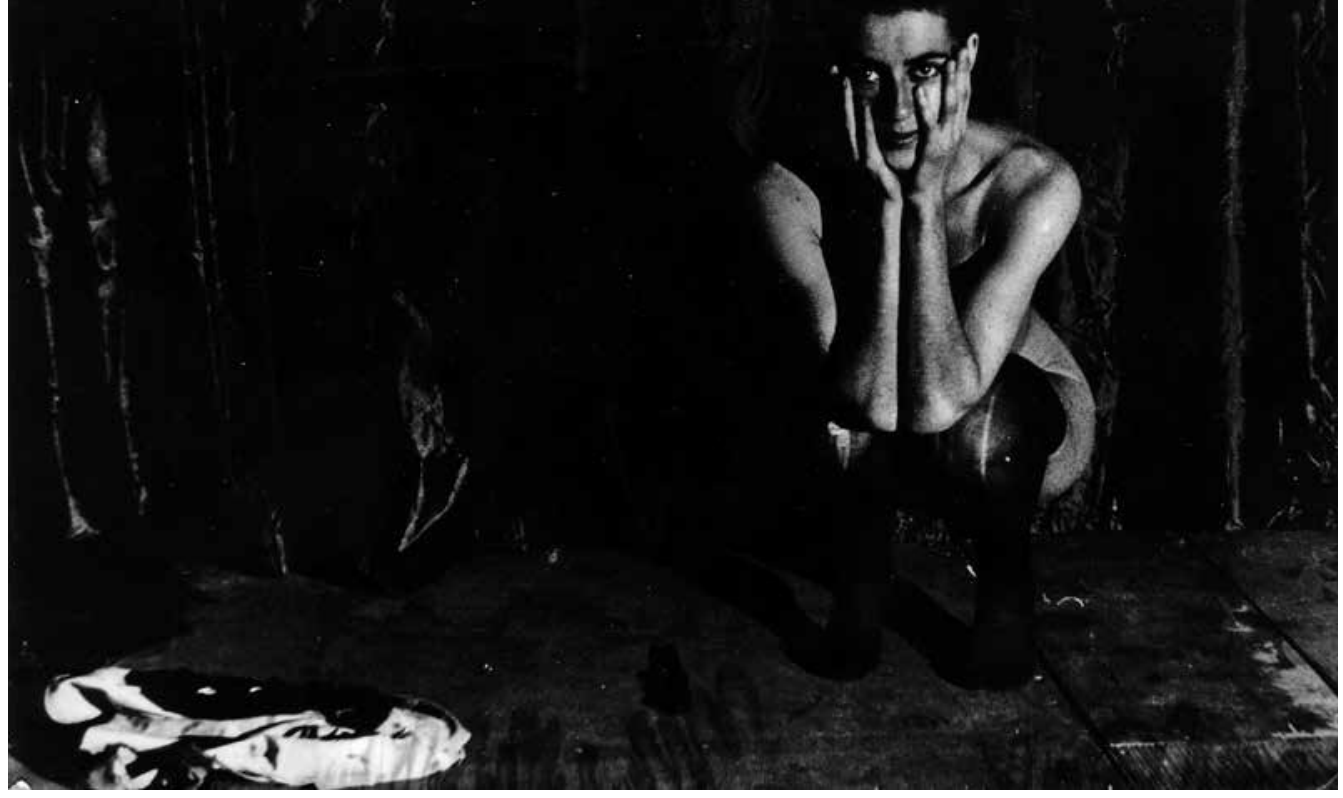

A VIRGEM DOIDA, A PARTIR DE RIMBAUD, CASA CONVENIENTE, 1992 (MÓNICA CALLE), [F] RUI POÇAS 


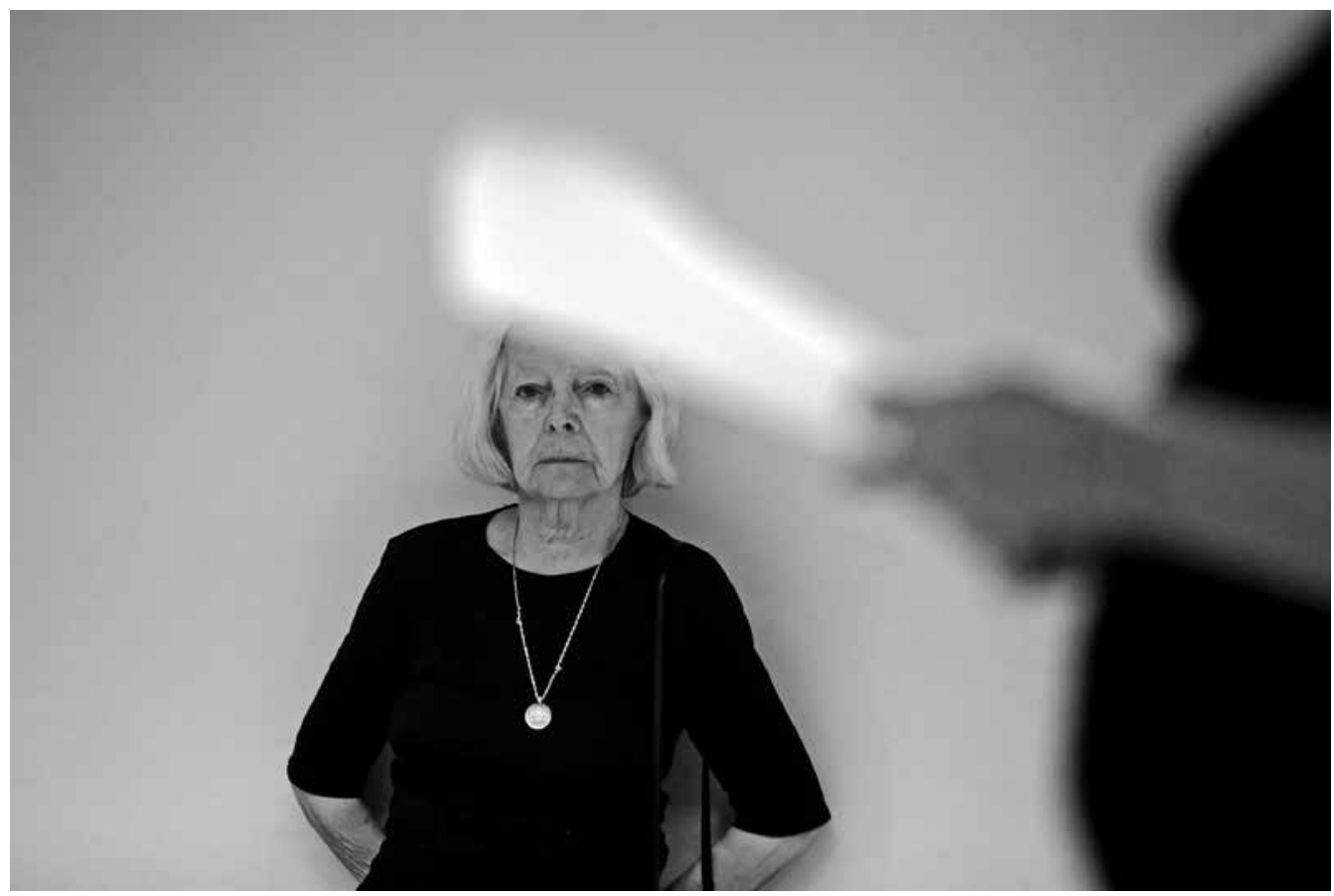

ILUMINAÇÕES, A PARTIR DE RIMBAUD, COMPANHIA MAIOR/CENTRO CULTURAL DE BELÉM, 2012 (ANA DIAS), [F] BRUNO SIMÃO

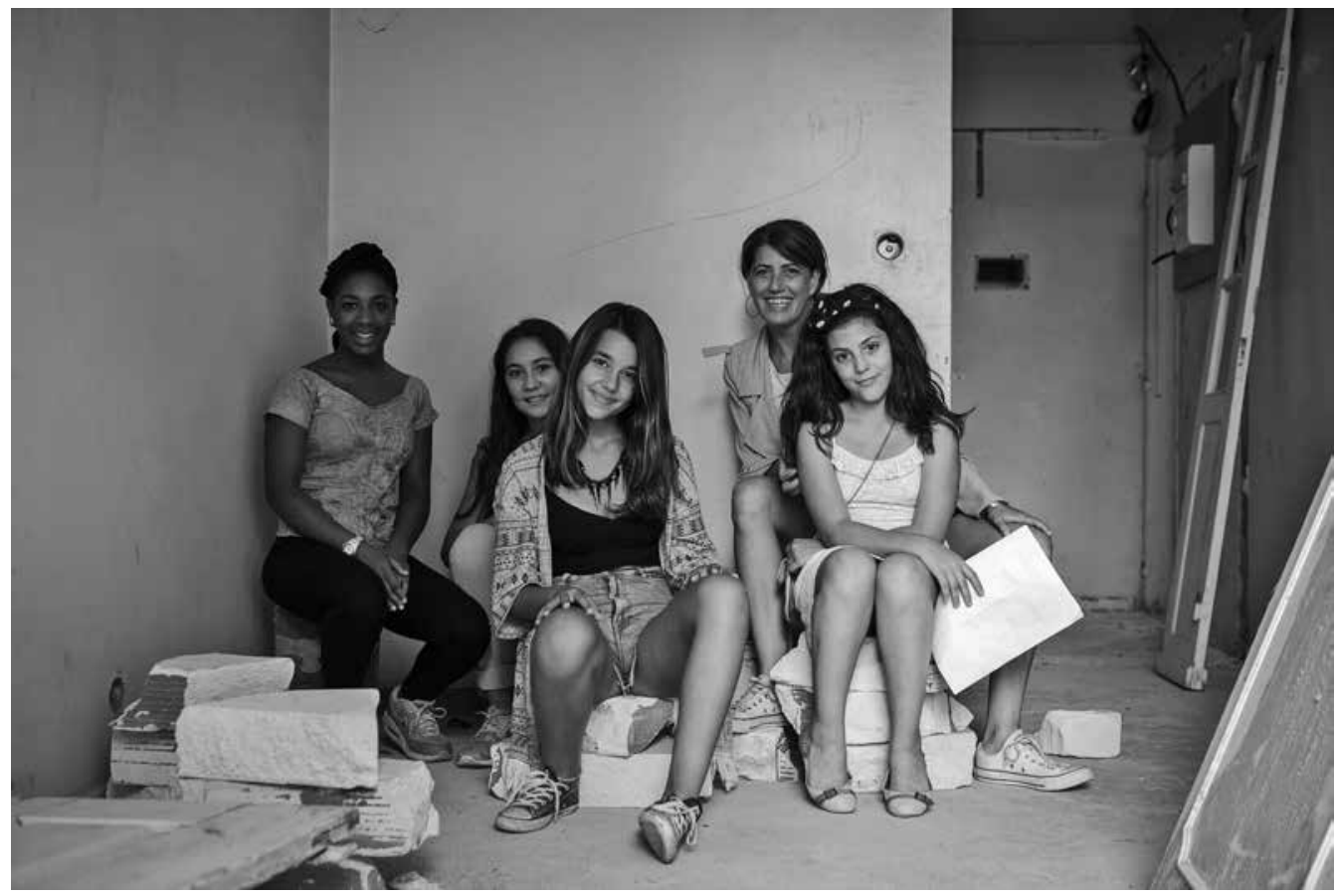

KEILA CAMARÁ, DANIELA GONÇALVES, ERICA RODRIGUES, MÓNICA GARNEL, LUANA FERREIRA, S. D. 
E isso leva-me a outra questão, que é a do trabalho a solo e do trabalho com outros actores. Há momentos em que a Mónica sente que precisa de estar a sós consigo a fazer uma coisa ou... A Boa Alma é um exemplo extraordinário, não é?

Tem que ver sempre com os momentos em que preciso de pensar, de repensar e de compreender onde estou e onde o meu trabalho está. São esses trabalhos a sós que também me permitem fazer experiências muito mais radicais, mais extremadas, mas que depois acabam por ter consequências no trabalho conjunto. Quando comecei a trabalhar com a Mónica Garnel e com a Ana Ribeiro (final dos anos noventa), fui deixando progressivamente de ser intérprete e, em 2011, voltei a perceber que preciso também... preciso de voltar a pensar o trabalho não só de fora, mas a partir de dentro. Decidi que não voltaria a ficar tanto tempo sem me pôr em cena, porque, do ponto de vista artístico, do ponto de vista pessoal e do trabalho, preciso de estar em palco. De pensá-lo e encontrá-lo enquanto intérprete.

Coincidiu com a tua perda de fé?

Também, também.

Procurar o que estava perdido?

Também, também.

Poderias retomar essa questão da fé? Fiquei curioso... Mas recuperaste a fé? Ou renovaste-a por outra coisa?

Perdi-a mesmo.

Agora recuperaste-a?

Estou a recuperá-la, sim. Recuperei. Neste momento voltei a sentir fé. Tenho fé.

E a experiência de Vale de Judeus foi determinante?

A experiência de Vale de Judeus... Eu sempre tive fé. Percebi que, na realidade, sempre tive fé e que a perdi... Ou seja, que estava a perdê-la. Na realidade, ter feito $A$ Virgem Doida... Tive de fazer essa descida e foi preciso fazê-lo pagando o preço para poder neste momento estar aqui a começar este projecto. Se o processo de ruptura e a violência dessa descida não tivesse sido tão profunda e tão brutal, eu, na realidade, não chegaria aqui preparada para estar 


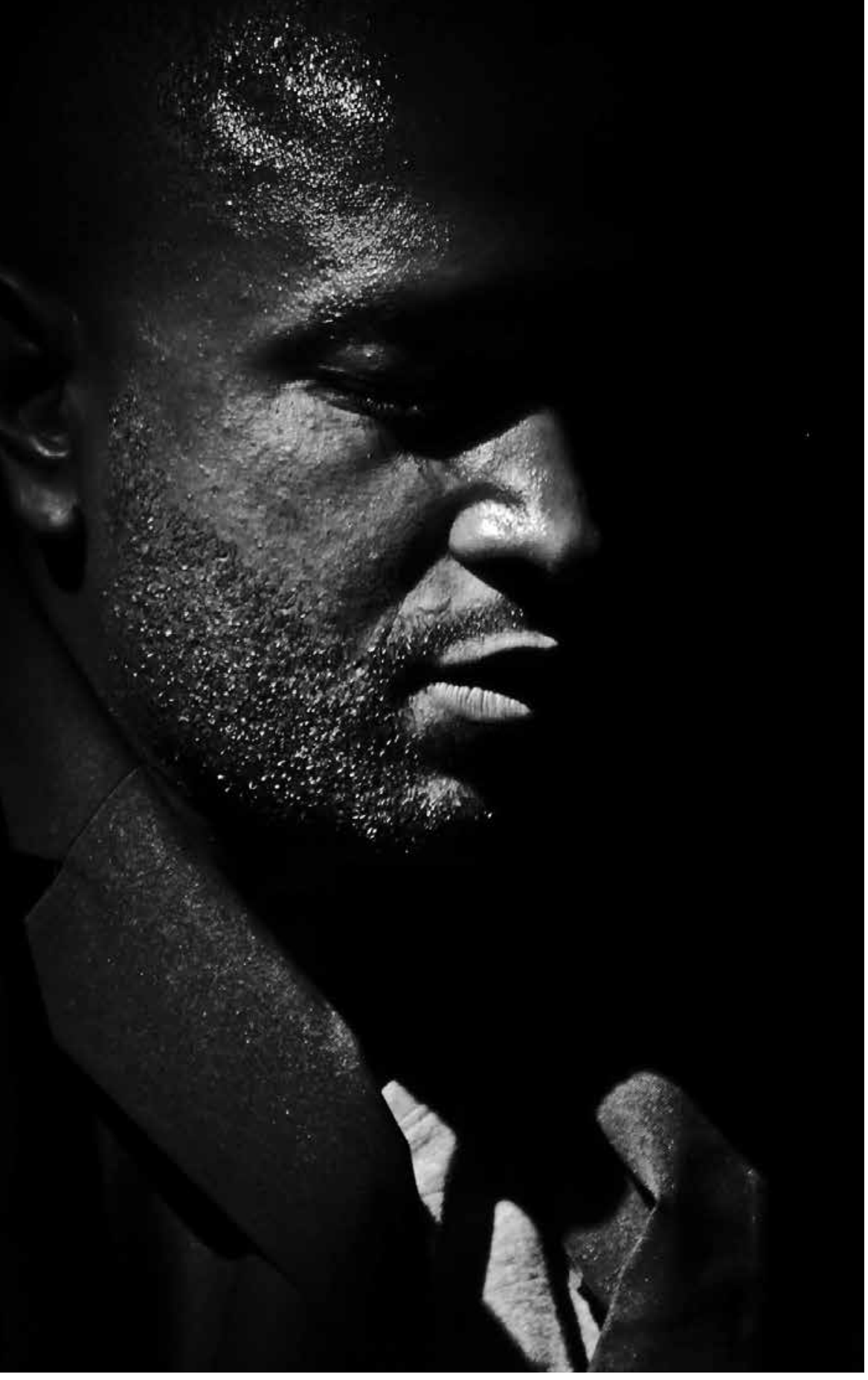

RECORDAÇÕES DE UMA REVOLUÇÃO, A PARTIR DE A MISSÃO, DE HEINER MÜLLER, CASA CONVENIENTE, 2011 (MÁRIO FERNANDES), [F] BRUNO SIMÃO 


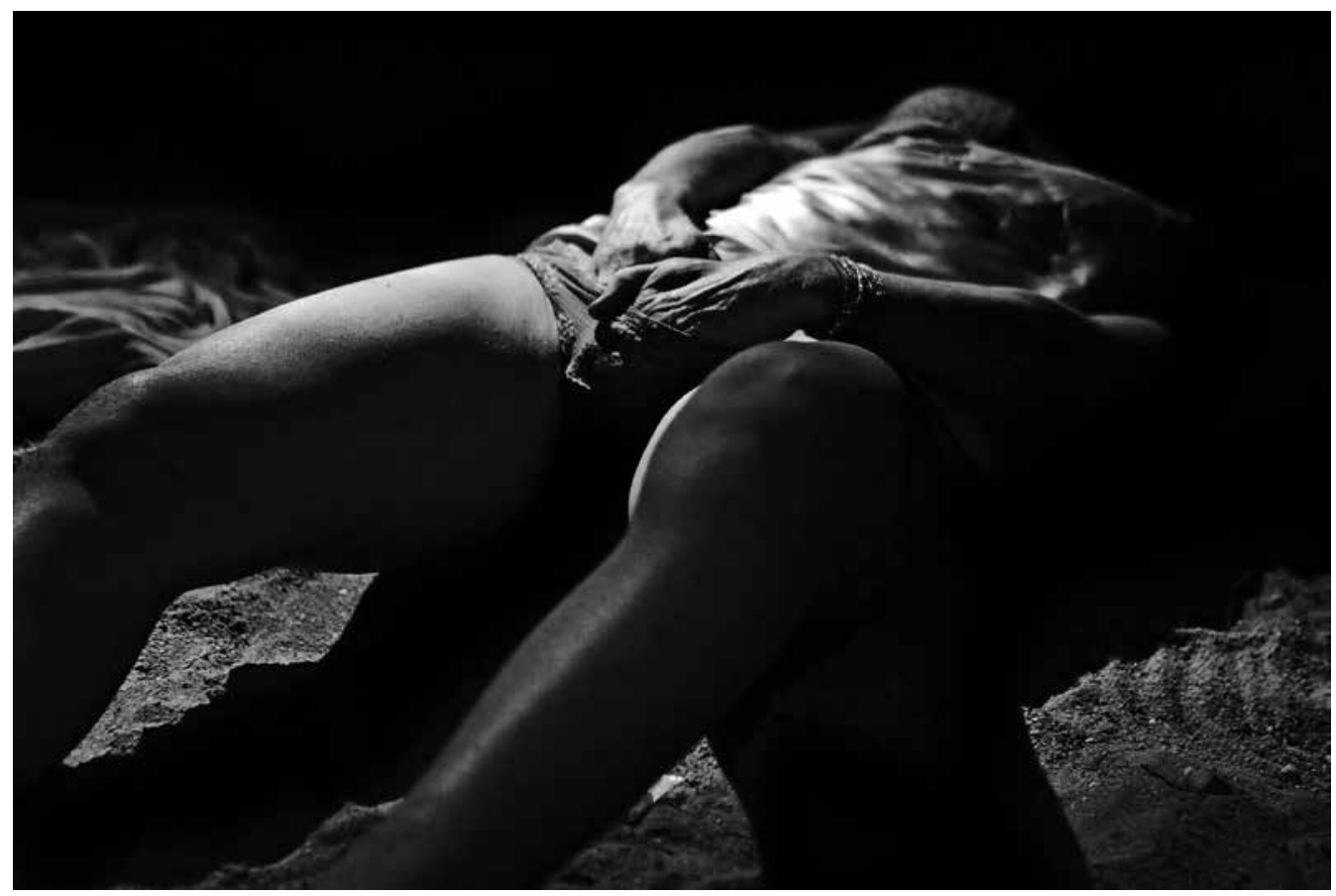

A VIRGEM DOIDA, A PARTIR DE RIMBAUd, CASA CONVENIENTE, 2012 (MÓNICA CALLE), [F] DE ENSAIO BRUNO SIMÃO

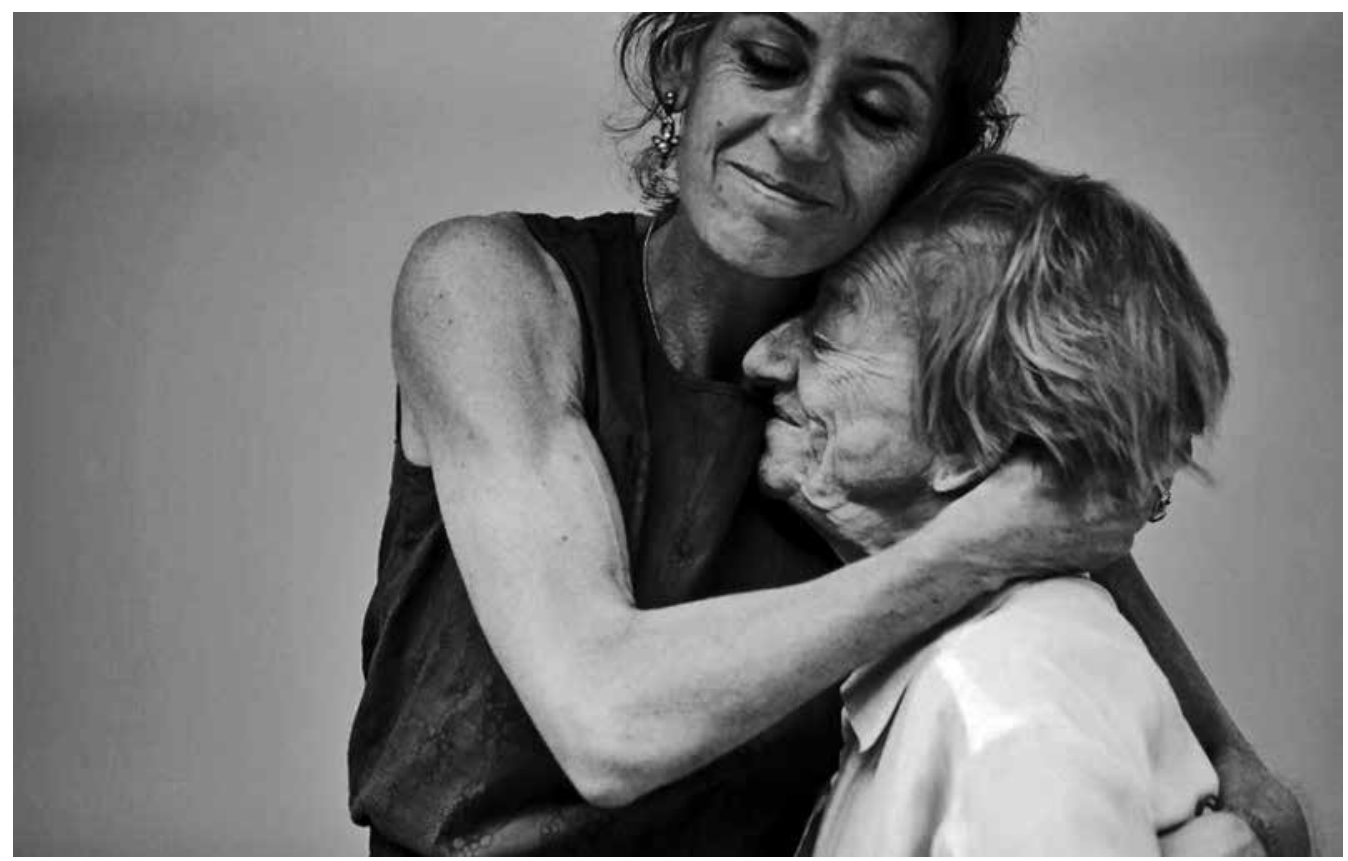

ILUMINAÇÕES, A PARTIR DE RIMBAUD, COMPANHIA MAIOR/CENTRO CULTURAL DE BELÉM, 2012 (MÓNICA CALLE, LUNA ANDERMATT) , [F] BRUNO SIMÃO 
aberta, atenta e disponível para isto tudo que estamos a começar aqui. Acho que foi necessário. Acredito que a vida é justa e que tudo tem um sentido. E acho que esse é o papel da arte. No fundo, a arte é isso: uma antecipação sem sabermos e uma disponibilidade que nos ultrapassa, para toda a vida. Para tudo. E conseguirmos trabalhar a partir disso. São esses momentos de sintonia em que às vezes estamos e outras vezes não estamos. Isso já me aconteceu várias vezes ao longo da vida. Não comecei a trabalhar de outra maneira, os meus pressupostos não se alteraram. Sem eu mesma perceber, estava encerrada. No fundo, ser veículo para uma data de coisas que depois transformo com aquilo que sou, ou seja, portanto, sempre passando por mim, mas passado para um contexto muito maior.

Nessa sequência sentes que encontraste o teu espaço, agora?

Não tenho qualquer dúvida. Tivemos muitas dúvidas o ano passado, porque estivemos em minha casa a fazer candidaturas e a pensar que nunca mais acontecia. $O$ caminho estava a ser construído, porque ao fazermos candidaturas estamos a pensar, só que nunca mais concretizávamos. Foi terrível. Nessa altura, muitas vezes questionávamos se fazia sentido vir para aqui.

Sentes que isto é ainda mais o teu espaço do que foi alguma vez a Casa Conveniente?

Da maneira como isto vai poder ser, não. Acho que isto é muito maior. O meu caminho foi construído ali, aquilo era um embrião. Neste momento tenho um trabalho de trinta anos que abriu. O meu trabalho foi abrindo. É uma escala maior. Isto permite, na realidade, trabalhar sobre mim e todas as questões que sempre procurei na minha vida pessoal, no meu trabalho.

Mesmo naquele início, não é?

Sim, também a ida para o Cais do Sodré foi isso, havia uma intuição: quero ir para um bairro que seja um sítio de margem, onde é possível misturar pessoas. Sempre houve essa intenção. É possível misturar, só que isto... Neste momento, há um trabalho. Há também uma escolha e uma maturidade que há vinte e sete anos não tinha. Foram vinte e sete anos da minha vida. 
Qual é a tua relação com os espaços?

A questão do espaço físico tem que ver com... No fundo, tem que ver com a relação com o público. Penso sempre no trabalho em função do público e da relação que vou estabelecer. Não é uma coisa que vem depois. Vem desde o primeiro dia, portanto, a questão do espaço está imediatamente ligada, porque tem que ver com a relação que vou estabelecer. Sei que, se puser o público de uma determinada maneira, a relação com o objecto é uma. Se o puser noutro sítio, a relação será outra. É em função da relação com o público que quero propor que penso o espaço. A questão da luz também começou logo com todo o trabalho artístico. Mas não só artístico, a ciência também, não é? Tem sempre que ver com as dificuldades e com como resolvemos os problemas. É sempre isso. Como se resolvem esses problemas? Que soluções encontramos? E com o trabalho dos actores também. No fundo, tem sempre que ver com uma ideia de resistência e de dificuldade e como as ultrapassas; como encontras soluções. Comecei por trabalhar sem dinheiro, portanto, não tinha projectores. Não tinha nada. O que havia? Lâmpadas. Lâmpadas com casquilhos. $\mathrm{E}$ eu comecei a fazer lâmpadas com casquilhos. A comprar fio eléctrico, a fazer uns casquilhos e a pôr umas lâmpadas. É uma coisa barata e aprendi a fazer. Todos nós sabemos fazer. Encontramos a solução. OK, não tenho projectores, mas não vou deixar de trabalhar a luz por isso. Percebi que podia trabalhar assim. Como também não tinha dinheiro para cenografia, aprendi a trabalhar sobre o que há. Aproveitar o que há, transformando. Percebi rapidamente que, por exemplo, pedir dinheiro não era viável, mas materiais de construção eram fáceis de arranjar. Depois também há esse lado que é pesado, é real, é concreto. Era possível arranjar materiais de construção, portanto comecei a arranjá-los e a trabalhar sobre o espaço físico e sobre esses mesmos materiais. Começa por uma questão muito concreta, mas depois obviamente que começa a ser pensado e torna-se uma opção. Ao longo destes anos podia ter comprado alguns projectores, ainda que pequenos; podia ter comprado uma mesa de luz... Até podia ter feito essa opção. Não o fiz, porque, de repente, isso para mim começou a ser mesmo construído e elaborado e uma escolha. Uma opção. Em relação à questão da luz: a luz, para mim, é matéria. Não é iluminação. Com a luz, se não tiver mais nada, consigo trabalhar sobre o espaço. A luz permite-me trabalhar o espaço. É matéria. 


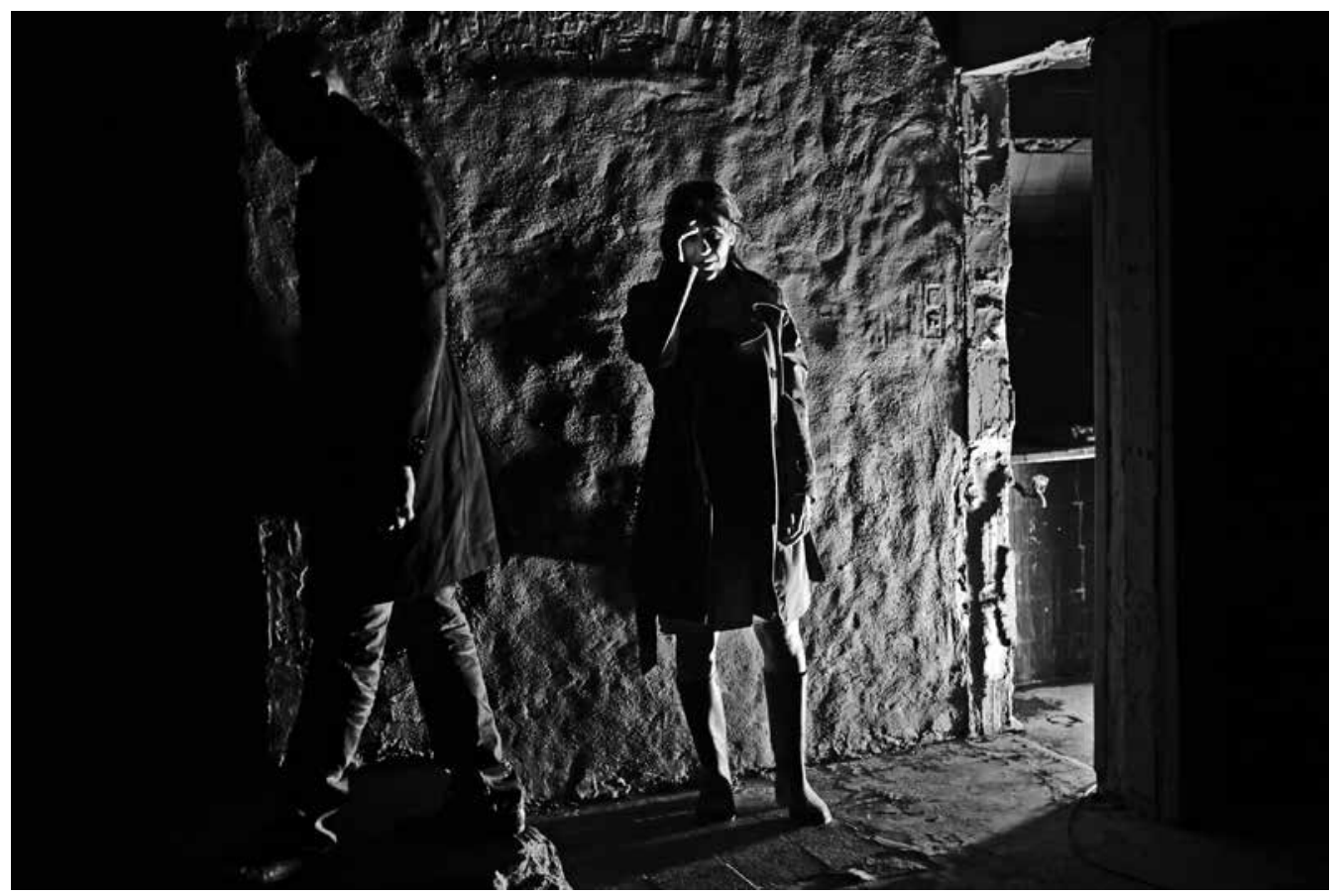

RECORDAC̣ÕES DE UMA REVOLUÇÃO, A PARTIR DE A MISSÃO, DE HEINER MÜLLER, CASA CONVENIENTE, 2011 (RENÉ VIDAL, MÓNICA CALLE), [F] BRUNO SIMÃO

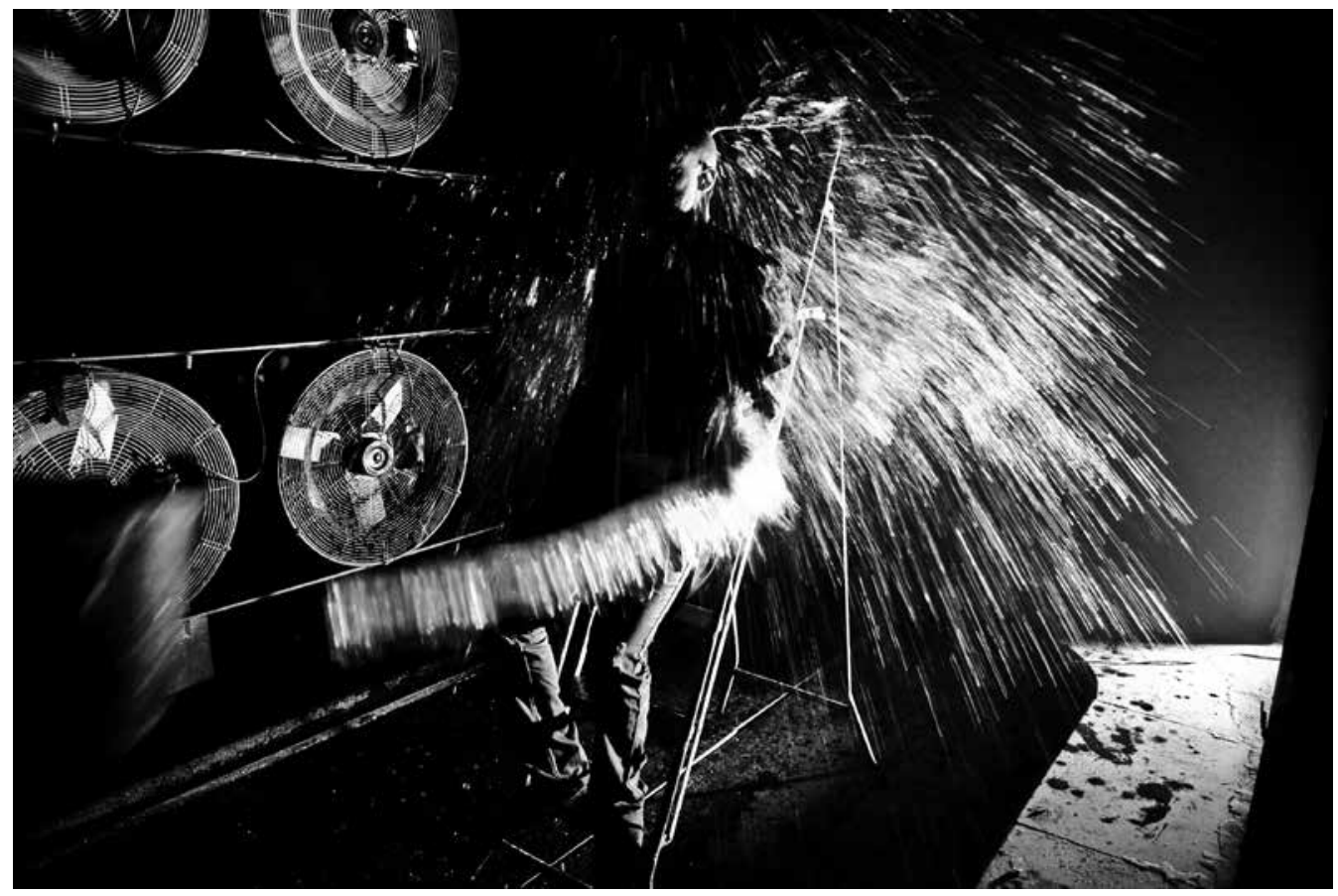

RECORDAC̣ÕES DE UMA REVOLUÇÃO, A PARTIR DE A MISSÃO, DE HEINER MÜLLER, CASA CONVENIENTE, 2011 (RENÉ VIDAL), [F] BRUNO SIMÃO 


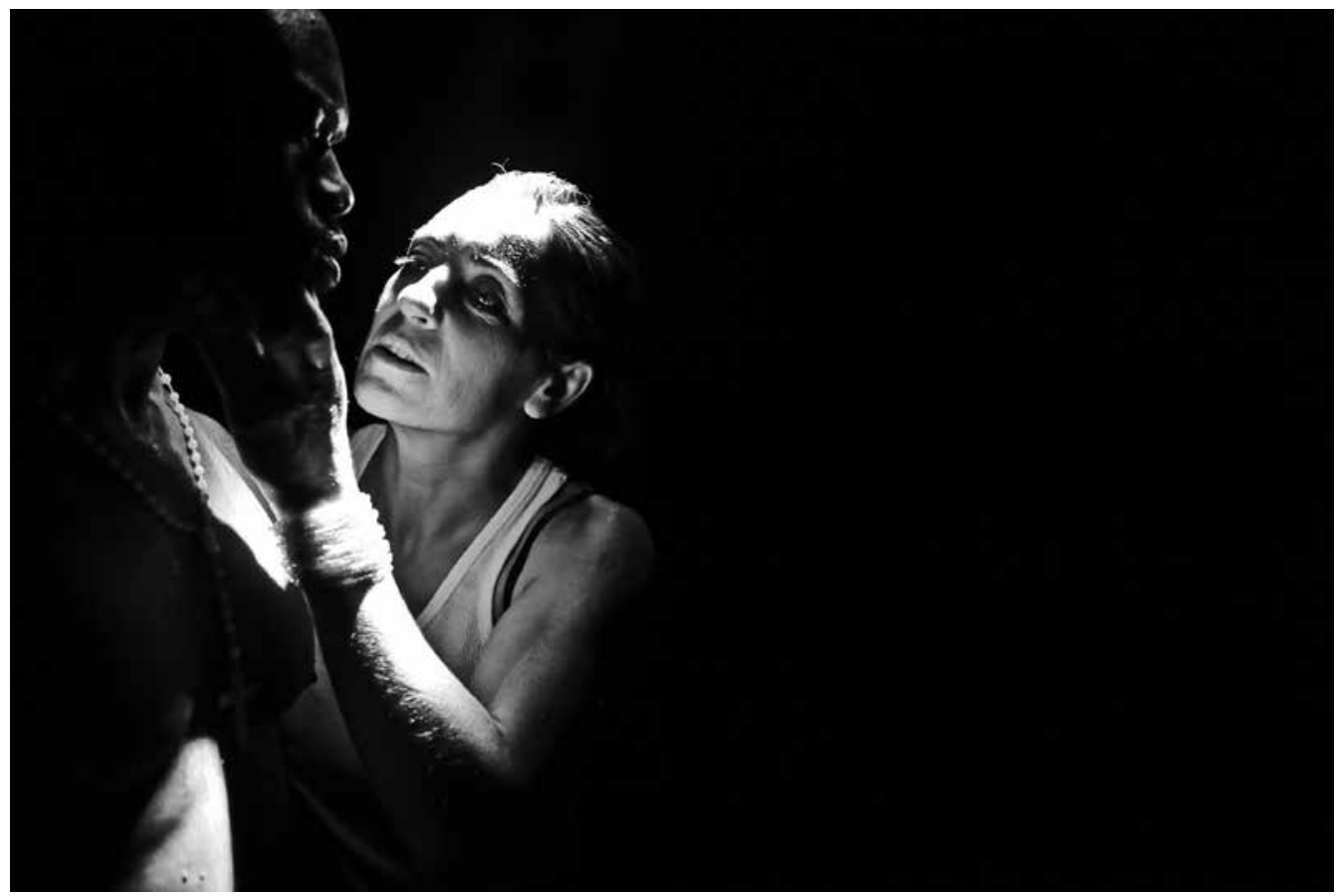

RECORDAÇÕES DE UMA REVOLUÇÃO, A PARTIR DE A MISSÃO, DE HEINER MÜLLER, CASA CONVENIENTE, 2011 (RENÉ VIDAL, MÓNICA CALLE), [F] BRUNO SIMÃO

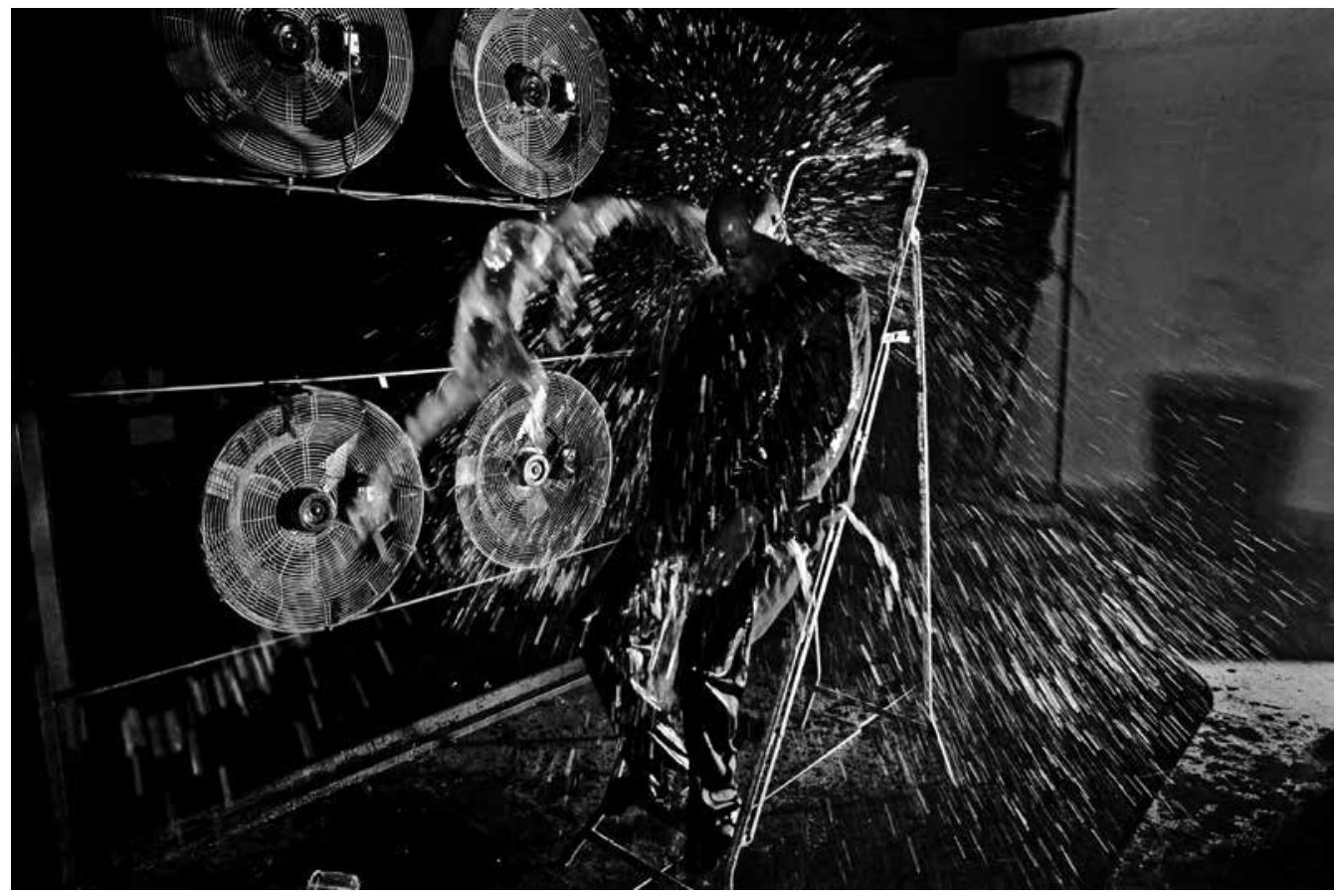

RECORDAC̣ÕES DE UMA REVOLUC̣ÃO, A PARTIR DE A MISSÃO, DE HEINER MÜLLER, CASA CONVENIENTE, 2011 (RENÉ VIDAL), [F] BRUNO SIMÃO 


\section{É a primeira a definir o espaço.}

É a luz, é matéria. Depois comecei a pensar cada vez mais nisso e sobre a ideia da escuridão, com o Caravaggio e com o Rembrandt. Gosto muito do trabalho de alguns pintores e fui também elaborando isso e vendo como eles faziam. A ideia em termos de colocação no espaço e deste jogo sempre de sombra e luz. O corpo iluminado, o corpo não iluminado. Para onde se olha? De onde vem o escuro e onde está a luz? Quando queremos trabalhar com muito pouca luz, onde têm os corpos de estar? Onde têm os actores de estar? Quais são os focos? O foco é sempre a direita de quem vê. Como trabalham os pintores a sombra? Onde se vê? A que se quer dar destaque? Depois penso na composição, quando trabalho com os actores, ao que quero dar relevância; é que eu trabalho sobre essas soluções de espaço. Sobre o que é importante em determinado momento. Comecei a perceber: se eu colocar do lado direito... Tem que ver com todos os pintores que trabalharam sobre o claro-escuro e trabalharam sobre esse tipo de noções. Fui introduzindo isso no meu trabalho e tenho pensado cada vez mais nisso. Mas também sobre uma ideia de... São os actores que também fazem tudo. Quem manipula todos os elementos são os intérpretes. Não há uma equipa técnica mesmo, por exemplo, quando trabalhamos fora em palcos. Aquilo que penso sempre, e cada vez tenho feito mais isso, é que as mesas de luz e de som venham para dentro da cena e, por exemplo, quando a Mónica ou a Sofia não entram, são elas que fazem a manipulação. Por exemplo, agora n'A Boa Alma, no Gil Vicente [Teatro Académico de Gil Vicente]... Consigo trabalhar muito bem com o José Álvaro Correia. Trabalhamos muito bem em conjunto. Se calhar porque ele tem uma noção de luz muito próxima da minha. Portanto, com ele tenho um entendimento muito justo, muito certo. E, além disso, até o espectáculo ser estreado, não consigo deixar de trabalhar. Estou sempre a mudar as coisas quando estou em cena. Quando se vai para um teatro maior, há uma equipa, portanto, às vezes é mais complexo poder trabalhar dessa forma. Nessa ideia que estamos todos os dias a mudar.

\section{Consegues fazê-lo com os técnicos?}

Consigo. Tenho muito boa relação com eles. Como estou mesmo verdadeiramente a trabalhar - tento incluir as pessoas todas no trabalho-, incluo a equipa toda e ponho-a a trabalhar comigo, 


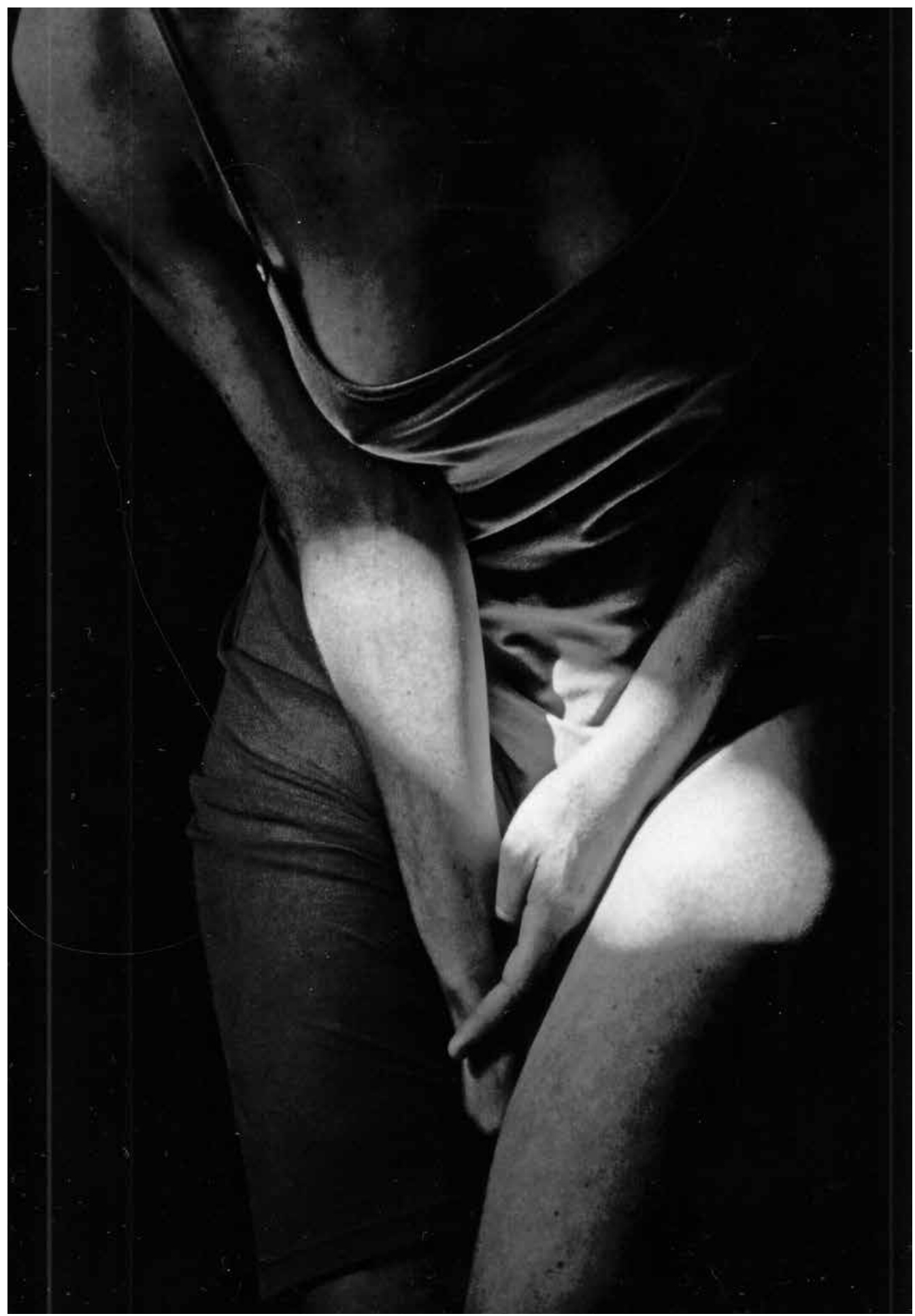

RUA DE SENTIDO ÚNICO, CASA CONVENIENTE, 2002 (MÓNICA CALLE), [F] JOÃO TUNA 
a ajudar-me e a dar opiniões. Eles fazem parte da equipa e estão a trabalhar mesmo. Tanto que consigo de facto trabalhar. As equipas também gostam que eu vá lá, porque sabem que não vão estar só a operar. Estão mesmo a trabalhar, a construir e a pensar comigo, a dar opiniões, a fazer parte. Com o Zé Álvaro... Ele sabe que vou mudar as coisas de um dia para o outro, portanto, normalmente o que ele faz é: prepara quarenta efeitos de luzes [risos]. A memória é gravada dia a dia, e eu depois escolho o que quiser e a ordem que quiser e deito umas fora num dia e depois escolho umas e escolho o que me apetece. Consigo trabalhar com ele assim.

E o cinema? O que lhe diz o cinema? A inspiração que pode ser o cinema? É outra linguagem? Ajuda a pensar a iluminação. Enfim, temos visto algumas pessoas do cinema a encenar. E a questão da luz é de facto muito engraçada quando estamos atentos ao modo como eles pensam a luz. Isso tem sido uma experiência para si também como actriz?

Só como actriz. Já fiz algumas coisas, mas poucas. A questão de, por exemplo, ser intérprete no cinema é muito difícil. Há uma certa frustração que acompanha o processo e é comum a todos os actores em Portugal, tirando aqueles que fazem - e são muito poucos bastante cinema. Ainda têm alguma regularidade. É que passa tanto tempo entre um filme e o outro, que a sensação é sempre a de que só quando estou a chegar ao fim do filme é que acho que vou conseguir perceber o que devia fazer, só que já não é possível. No momento em que acabo o filme é que estaria pronta para trabalhar sobre aquela linguagem, só que entretanto são mais dez anos. Mas pensar em fazer um filme... Sim, já pensei. Tinha vontade. Acho que um dia hei-de experimentar fazer. Gostava bastante. Não sei quando, mas vou experimentar, porque tenho alguns projectos...

E coisas que não foram feitas até agora, que ainda não foi o momento, ou porque as circunstâncias às vezes materiais não permitiram? Há assim uma coisa absolutamente incontornável?

Há várias. Por exemplo, voltar ao Macbeth, do Heiner Müller, que é muito parecido com o do Shakespeare. Voltar a Beckett. Um dia trabalhar sobre o Romeu e Julieta, de Shakespeare, que é uma peça da qual gosto muito. 


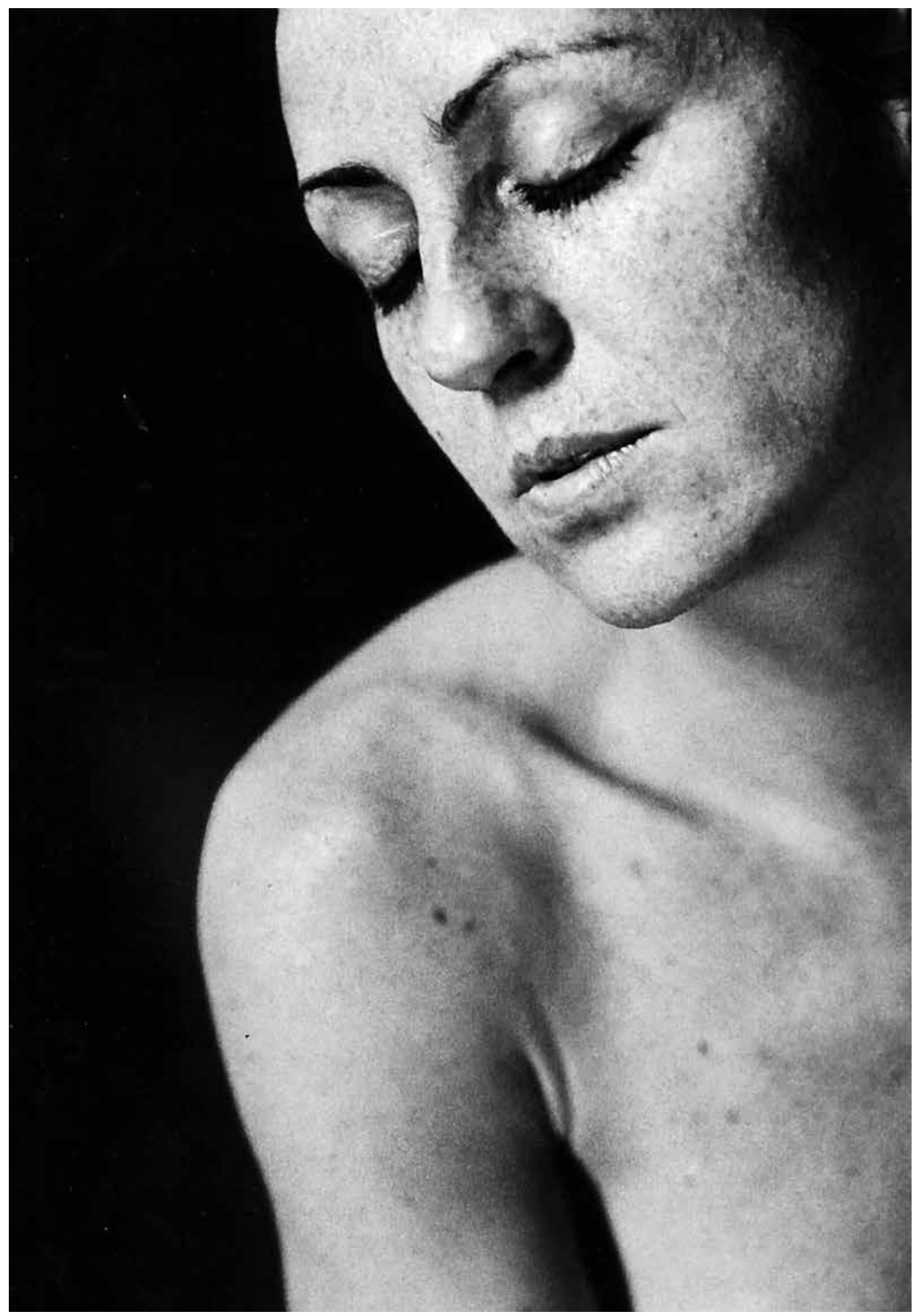

RUA DE SENTIDO ÚNICO, CASA CONVENIENTE, 2002 (MÓNICA CALLE), [F] JOÃO TUNA 


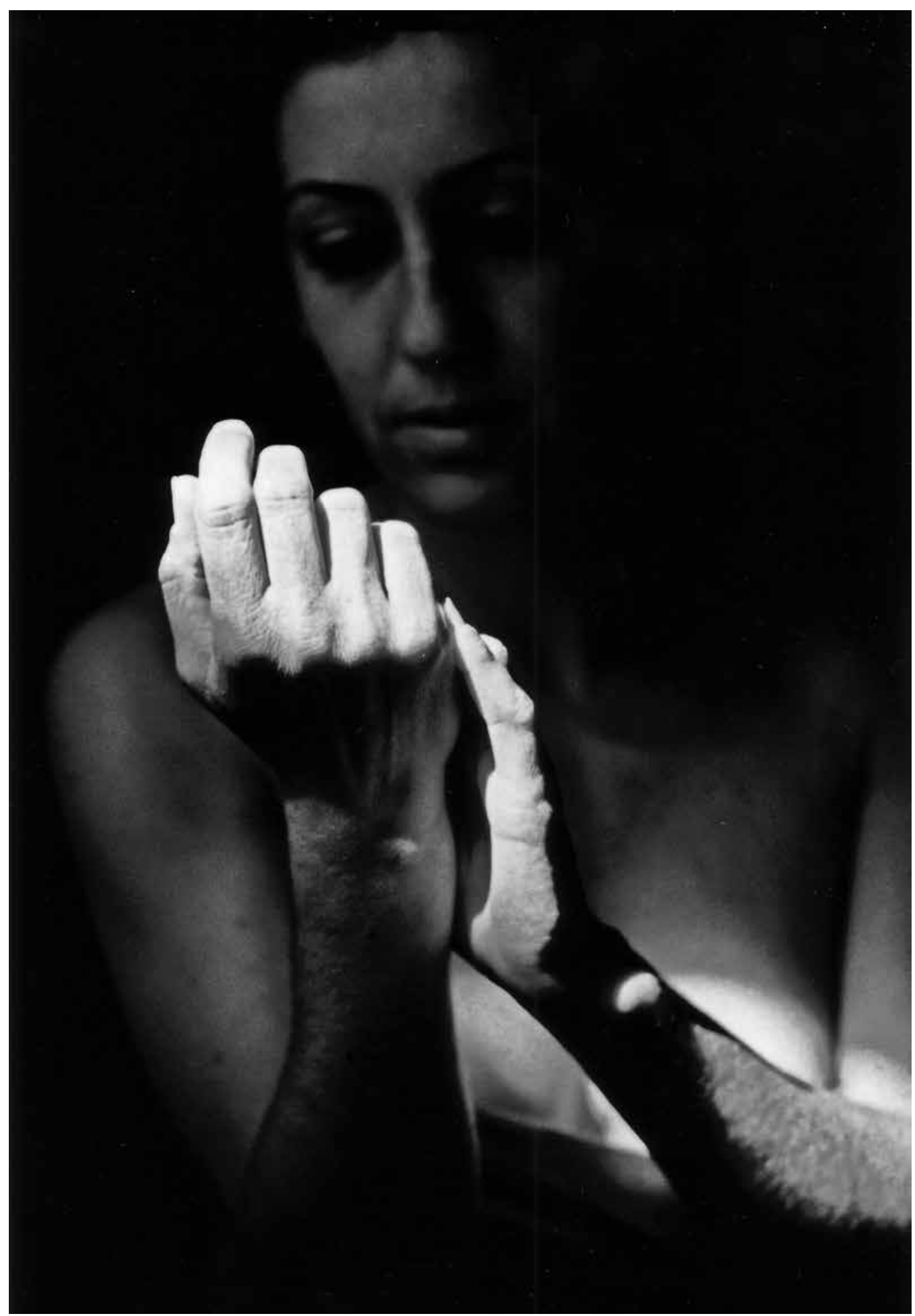

RUA DE SENTIDO ÚNICO, CASA CONVENIENTE, 2002 (MÓNICA CALLE), [F] JOÃO TUNA 


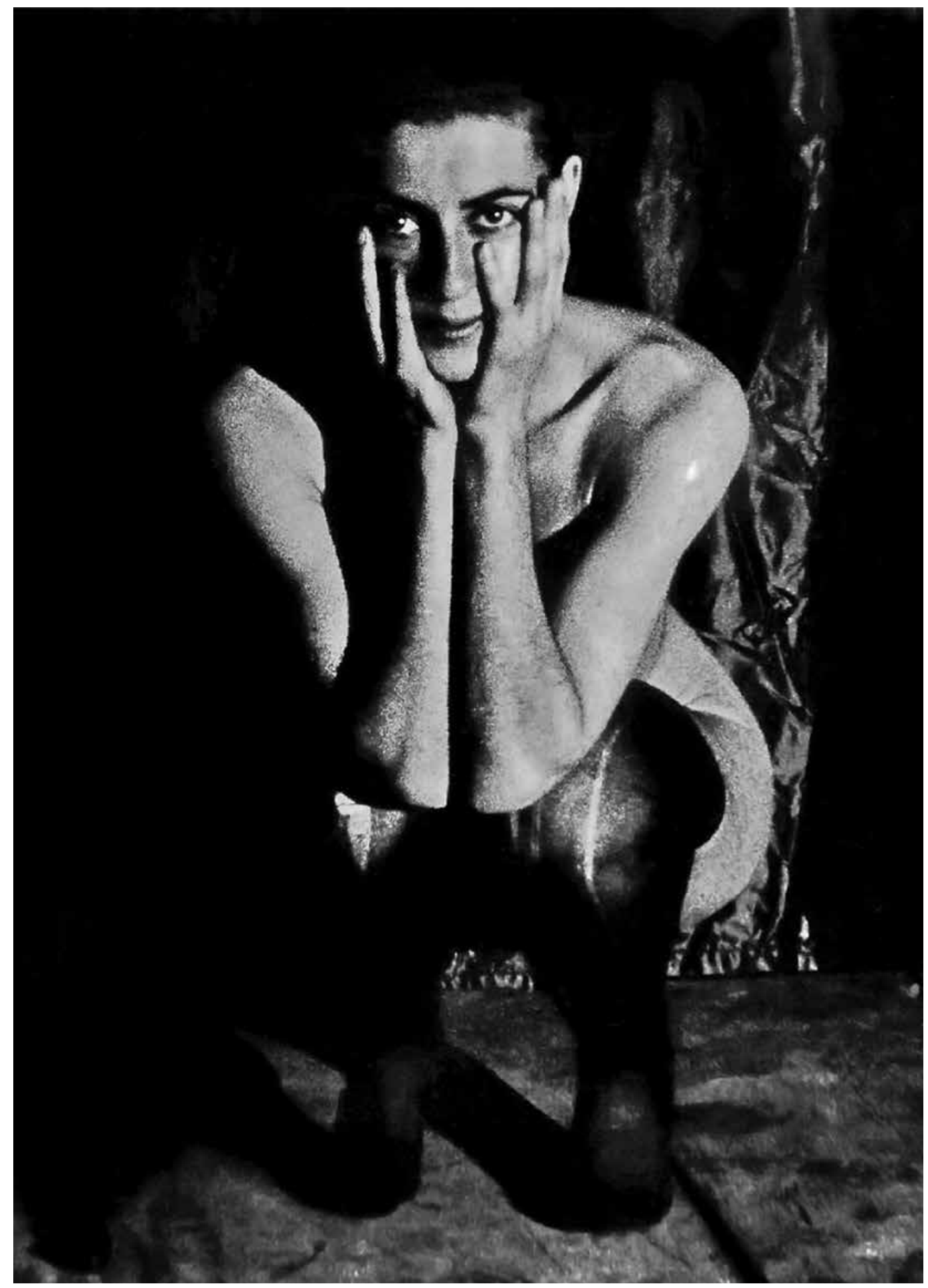



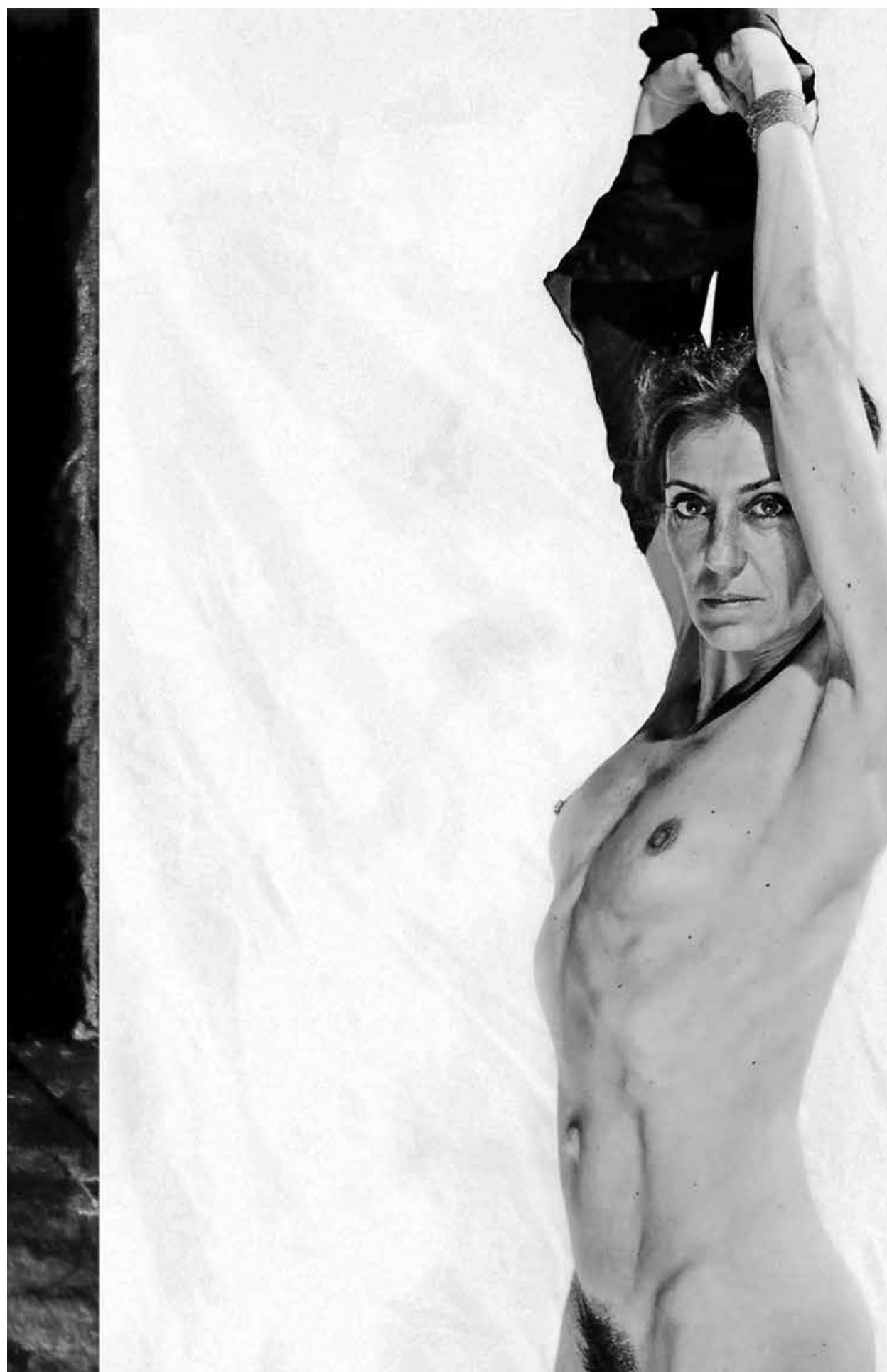
E coisas contemporâneas?

Esta dramaturgia europeia dos últimos vinte anos não me interessa. Tem que ver com uma noção de linguagem demasiado próxima da realidade e da disfunção familiar.

Transporta uma visão negra, de falta de esperança?

Nem é só isso. É mesmo uma questão de linguagem. Não gosto da qualidade da linguagem. Não gosto de textos em que a palavra seja banal. De alguma forma, se calhar em todos os autores de que gosto mais e sobre os quais gosto de trabalhar, esse pensamento sobre a língua está sempre presente. O Rimbaud, o Müller, o Beckett, o Thomas Bernhard...

Em que a língua é um desafio.

É também a própria questão. Fiz um espectáculo em Marselha, Rua de Sentido Único, que era uma colagem de textos de vários autores. Acabou por ser um texto um bocadinho inédito, porque depois já nem sabia quais eram, de onde vinha o quê, mas usava partes do Rimbaud, ligadas a outros textos. A mãe da Mónica [Garnel] traduziu-me o texto para francês, mas obviamente que não foi preciso traduzir Rimbaud. Quando cheguei a Marselha para fazer o espectáculo em francês, comecei a trabalhar com algumas pessoas da universidade e pedi-lhes para me reverem o texto. $\mathrm{E}$ foi incrível, eu nem disse nada, tive vergonha de o fazer. As únicas frases que foram corrigidas foram as do Rimbaud. Ainda hoje a estranheza que ele causa e a forma como ele trabalhou...

E se apropria da língua.

Sim, se apropria e joga com a língua e todas as questões de língua e da organização. Ainda hoje é... Eu nem disse nada, porque era uma professora universitária. Aquilo estava misturado, mas eu fiquei... Achei incrível como o Rimbaud continua a ser tão revolucionário ainda.

Como passaste dessa paixão pela palavra para o teatro?

Qual foi o salto...? Ou sentes que o teatro é a maior celebração possível da palavra?

Tem que ver com a oralidade e com a partilha da palavra. Com a possibilidade de a palavra estar viva e ter corpo. Ser corpo. Tem que ver com isso. $O$ teatro é essa possibilidade de a palavra ser corpo. 